NBER WORKING PAPER SERIES

\title{
SPECIALIZATION, FIRMS, AND MARKETS: \\ THE DIVISION OF LABOR WITHIN \\ AND BETWEEN LAW FIRMS
}

\author{
Luis Garicano \\ Thomas N. Hubbard \\ Working Paper 9719 \\ http://www.nber.org/papers/w9719
NATIONAL BUREAU OF ECONOMIC RESEARCH
1050 Massachusetts Avenue
Cambridge, MA 02138 \\ May 2003
}

Thanks to Tim Bresnahan, Judy Chevalier, Rob Gertner, Jack Heinz, Ed Laumann, Jonathan Levin, Kevin Murphy, Bob Nelson, Ben Pollack, Canice Prendergast, Tano Santos, Jeffrey Sheffield, Bob Topel, Mike Whinston and many seminar participants for useful discussions, and to the Chicago GSB and the Kaufmann Foundation for support. The research in the paper was conducted while the authors were Census Bureau research associates at the Washington and Chicago Research Data Centers. Research results and conclusions are those of the authors and do not necessarily indicate concurrence by the Bureau of the Census. This paper has been screened to insure that no confidential data are revealed.The views expressed herein are those of the authors and not necessarily those of the National Bureau of Economic Research.

C2003 by Luis Garicano and Thomas N. Hubbard. All rights reserved. Short sections of text not to exceed two paragraphs, may be quoted without explicit permission provided that full credit including (C) notice, is given to the source. 
Specialization, Firms, and Markets: The Division of Labor Within and Between Law Firms Luis Garicano and Thomas N. Hubbard

NBER Working Paper No. 9719

May 2003

JEL No. L11, L14, L22, L84

\begin{abstract}
What is the role of firms and markets in mediating the division of labor? This paper uses confidential microdata from the Census of Services to examine law firms' boundaries. We find that firms' field scope narrows as market size increases and individuals specialize, indicating that firms' boundaries reflect organizational trade-offs. Moreover, we find that whether the division of labor is mediated by firms differs systematically according to whether lawyers in a particular field are mainly involved in structuring transactions or in dispute resolution. Our evidence is consistent with hypotheses in which firms' boundaries reflect variation in the value of knowledge-sharing or in the costs of monitoring, but not in risk-sharing. Our findings show how the incentive trade-offs associated with exploiting increasing returns from specialization lead the structure of the industry to be fragmented, but highly-skewed.
\end{abstract}

Luis Garicano

University of Chicago

Graduate School of Business

1101 East $58^{\text {th }}$ Street

Chicago, IL 60637

luis.garicano@gsb.uchicago.edu
Thomas N. Hubbard

University of Chicago

Graduate School of Business

1101 East $58^{\text {th }}$ Street

Chicago, IL 60637

and NBER

thomas.hubbard@gsb.uchicago.edu 


\section{Introduction}

As economists since Adam Smith have observed, individuals tend to become more specialized as the size of the market increases. Once individuals specialize, economic institutions become necessary to mediate relationships among them. When is the division of labor efficiently mediated by firms? When is it efficiently mediated by markets? In addressing these questions, we seek to illuminate the role firms and markets play in the organization of human capital. This organizational issue has become increasingly salient as service sectors' share of developed economies has grown, because these sectors tend to be human capital-intensive. ${ }^{1}$

This paper investigates the determinants of law firms' field boundaries. Our analysis relies on law office-level data collected by the Bureau of the Census. A key question in the survey form law offices receive asks how many lawyers in the office specialize in each of 13 areas of the law. This question provides evidence not only on law firms' scope, but also the scope of individual lawyers' expertise. It allows us to examine patterns of individual specialization, how specialists are organized into firms, and relationships between the two: how does the division of labor across individuals affect the division of labor across firms? The data provide us a rare opportunity to empirically investigate the organization of human capital, and study the role of firms in facilitating specialization.

We employ two empirical approaches. The first approach investigates whether and how firms' boundaries are sensitive to the division of labor. We investigate whether lawyers specialize more as market size increases, and if so whether the share of lawyers working in fieldspecialized firms increases as well. This provides evidence regarding whether law firms' boundaries reflect only the distribution of individual clients' demands, or reflect organizational trade-offs: whether firms or markets best mediate relationships between lawyers. The latter affect firms' boundaries only when fields are covered by multiple lawyers. The second approach examines which types of specialists tend to work in the same firm and which tend not to do so. Unlike the first approach, this approach provides no evidence on how firms' boundaries change with the division of labor, since individuals' specialties are held constant. But it provides more detailed evidence with respect to law firms' field composition. We use this evidence to examine 
various hypotheses regarding what drives organizational trade-offs with respect to firms' boundaries: if law firms' boundaries reflect Coasian organizational trade-offs, what is the nature of such trade-offs? These hypotheses focus on the benefits and costs of revenue-sharing arrangements. In particular, we consider the possibility that law firms' field boundaries reflect variation in the value of knowledge-sharing, risk-sharing, and monitoring costs.

Results from the first approach indicate that lawyers specialize more as market size increases. We find that the share of lawyers that work in field-specialized firms does as well. This is evidence firms' boundaries sometimes narrow as market size increases and individuals specialize. It is inconsistent with the proposition that firms' boundaries reflect only the distribution of clients' demands, and consistent with the hypothesis that they are shaped by organizational trade-offs: whether firms or markets best mediate relationships between lawyers. We find that this relationship differs systematically across fields according to whether clients primarily demand expertise in the process of structuring transactions ("ex ante" fields) or in the process of resolving disputes revolving around existing contractual relationships ("ex post" fields). We find no evidence that firms' boundaries narrow as individuals' specialize in ex ante fields: as lawyers specialize more in ex ante fields such as corporate law, there is no indication that relationships between them and lawyers in other fields are increasingly mediated by markets rather than firms. In contrast, our evidence suggests that firms' boundaries narrow as lawyers specialize in ex post fields: fields such as insurance law tend only to be covered in the same firm as other fields when insurance law and other fields are covered by the same lawyer.

Results from our second approach indicate that lawyers are more likely to work at the same firm with other lawyers in the same field than in any other field. We also find that lawyers in ex ante fields that serve business demands tend to work at the same firm as lawyers in any of the ex ante business fields, and tend not to work at the same firm as lawyers in either ex post business fields or fields that serve individual demands. For example, specialists in corporate law tend to work at the same firm as specialists in real estate law, but not specialists in insurance or criminal law. There are two exceptions to this general pattern. One is that patent lawyers generally do not work at the same firm as specialists in other ex ante business fields. The other

\footnotetext{
${ }^{1}$ In the U.S., the service sector's share of GDP (not including financial services) increased from $12 \%$ to $22 \%$ between 1970 and 2000; this sector is currently about 40\% larger than manufacturing. In contrast, manufacturing's share fell from $24 \%$ to $16 \%$ during this time. See Economic Report of the President, February 2002, p. 336.
} 
is that probate lawyers, specialists who serve individual clients, tend to work at the same firm as ex ante business specialists. For example, the scope of firms that have corporate or real estate specialists generally tends not to include patent law but does tend to include probate law, accounting for patent and probate lawyers' share of the industry overall.

We conclude that this second set of results provides no evidence for the hypothesis that law firms' field boundaries are shaped by revenue sharing arrangements' risk-sharing benefits: specialists in fields with positively correlated demands tend to work at the same, not different, firms. Some version of knowledge-sharing or monitoring cost hypotheses could explain these results. Absent detailed information about knowledge sharing patterns or monitoring, it is difficult to distinguish among these hypotheses because they all imply that the relative benefits of mediating relationships within firms should be higher for fields that are somehow closely related. We therefore provide some additional evidence on compensation and collaboration patterns from a recent survey of Chicago lawyers taken by researchers at the American Bar Foundation. Results from this survey indicate that encouraging referrals, knowledge-sharing about economic opportunities, is an important organizational objective within law firms. Other results indicate that if within-firm monitoring is important, it must support incentive instruments that do not directly affect how revenues are shared. Finally, we find that a substantial share of partners rarely, if ever, collaborate with other partners in their firm, indicating that the organizational benefits of revenue-sharing arrangements extend beyond facilitating the exchange of client or legal knowledge between lawyers.

Beyond deepening our knowledge of the role of firms in human capital intensive contexts, our findings help illuminate several other issues, traditionally addressed by different literatures. First, our findings on the horizontal scope of firms have bearing on the determination of industry structure, a key concern of the industrial organization literature. ${ }^{2}$ Second, an understanding of the effect of market size in the organization of work and the horizontal division of labor is key to the study of the sources of agglomeration effects in cities and their role in economic growth, a concern of the new urban economics literature. ${ }^{3}$ Third, our empirical evidence illuminates the grouping of task types into jobs and of jobs into firms in law firms and, as such, is of interest to the recent labor economics literature dealing with the problems of the

\footnotetext{
${ }^{2}$ Sutton $(1991,1998)$.

${ }^{3}$ See e.g. Glaeser et al (1992), Lucas and Rossi-Hansberg, (2002).
} 
breadth of task assignment and of job design. ${ }^{4}$ Finally, understanding the sources of the tradeoffs involved in the coordination of specialists is relevant to the growth literature that, building on Smith and Young (1928), investigates the determinants of specialization and the impact of specialization on economic growth. ${ }^{5}$

The rest of the paper is organized as follows. Section 2 discusses Coasian and nonCoasian views of firms' boundaries, relates them to our context, and describes our general empirical approaches. Section 3 presents the data. Section 4 presents results from our first empirical approach, which investigates whether and how firms' boundaries change with the division of labor. Section 5 presents and discusses results from our second empirical approach, which analyzes patterns in firms' field composition. Section 6 presents survey evidence on compensation and collaboration patterns within law firms. Section 7 concludes.

\section{Understanding the Boundaries of the Law Firm}

\subsection{Law Firms and the Scope of Client Demands}

A prevailing view of the scope of law firms is that it is client-centered. Support for this view can be found in Heinz and Laumann's (1982) study of the Chicago bar. ${ }^{6}$ This study, which is perhaps the leading sociological analysis of the organization of professional services, stresses how the type of client served shapes the organization of legal services. Heinz and Laumann conclude that the bar is divided in two "hemispheres" that correspond to client type: the corporate bar and the individual bar. Lawyers in these two hemispheres are so distinct in their training, practice, and socio-economic characteristics so as to be considered within different professions (1982:174). These authors conjecture that this division of the bar's social structure is reflected by a sharp distinction between law firms that serve corporate and individual clients; those that serve corporate clients do not serve individual clients and vice-versa. Within each of these "hemispheres," and particularly in the corporate one, lawyers will tend to specialize, but the firm will "feel the pressure to serve a broad range of the demands of the firm's clients" (1982:131).

\footnotetext{
${ }_{5}^{4}$ See e.g. Holmstrom and Milgrom, (1991), Olsen and Torsvik, (2000).

${ }^{5}$ See e.g. Romer (1986, 1987).

6 The study is based on hour long interviews with 777 Chicago lawyers. Being the first in-depth study of a profession, it is now considered a classic in sociology.
} 
An analogous, demand-centric view of firms' scope exists within the industrial organization literature as well. This view posits that scope economies can be demand-based, derived from "one-stop-shopping" economies. A precise modern statement of this view holds that in the presence of shopping costs $^{7}$ multiproduct firms exist to "offer a variety of products at a single destination" (Klemperer and Padilla, 1997:472). ${ }^{8}$ The scope of the firm is then shaped by firms' desire to capture externalities between product lines due to these shopping costs. As applied to legal services, this view has implications that are similar to the sociological view depicted above: law firms' scope should reflect only the scope of clients' needs, and not problems associated with mediating relationships between lawyers.

An implication of these demand-centric views is that firm scope should not change as market size increases if the composition of demand is held constant. If firms' scope simply reflects the scope of individual clients' demands, doubling market size by simply replicating the demands of existing clients should not affect firms' scope, since replicating demands does not alter the scope-distribution of clients' demands.

\subsection{Organizational Trade-offs and Law Firm Boundaries}

Since Coase (1937), economists have viewed firms and markets as alternative institutional structures through which economic activity is coordinated. Whether firms or markets efficiently mediate the division of labor, and thus best promote specialization, depends on which structure minimizes transaction costs. Modern theories of organization have since built from Coase by proposing what differentiates transacting within versus between firms, then analyzing the trade-offs associated with using firms and markets. While the details of these theories differ, they share the Coasian view that firms' boundaries reflect organizational tradeoffs; in this context, that they reflect whether relationships between lawyers are best mediated within firms or by markets. What distinguishes this view from the demand-centric views above is that it emphasizes that firms' boundaries are determined not by demand patterns (e.g., whether

\footnotetext{
${ }^{7}$ Shopping costs are the real or perceived costs of using additional suppliers (Klemperer (1992)).

${ }^{8}$ Strategy researchers have also argued that offering demanders one-stop-shopping is a particular advantage of broad scope (e.g. Porter (1985)).
} 
clients find expertise in different fields complementary), but by how relationships between suppliers are best organized.

In the rest of this subsection, we discuss a general implication of the Coasian view; in the subsection that follows, we propose what defines firms' boundaries in the context of legal services, and discuss in more detail what might drive differences in the relative costs of transacting within and between firms in this context.

The Coasian logic suggests a natural way for investigating whether organizational tradeoffs affect firms' boundaries: examine whether firms' boundaries narrow as market size increases and individuals become more specialized. We depict this in Figure 1. Suppose one can partition knowledge into fields of expertise. The dashed lines depict the scope of individuals' expertise, and the solid lines depict how individuals are grouped into firms. In the Figure, one individual covers both field $\mathrm{A}$ and other fields in small markets but different individuals cover field A and other fields in large markets. As market size increases, individuals specialize in field A.

When a single individual covers both field A and other fields, the scope of his or her firm includes field A and other fields. Organizational trade-offs, which appear only when different individuals cover field A and other fields, do not affect whether the firm's scope includes field A and other fields. Firms' scope tends to be broad because individuals cover multiple fields. But once individuals specialize, firms' scope depends not just on the range of individuals' expertise, but also on whether firms or markets mediate the division of labor efficiently. When firms do, firms' boundaries should not change as individuals specialize. When markets do, firms' boundaries should narrow. In the Figure, if markets efficiently mediate relationships between individuals in field A and other fields, then firms' scope should include field A and other fields only when these fields are covered by the same individual.

One can therefore test whether organizational trade-offs affect firms' boundaries by examining whether firms' boundaries change with increases in the size of demand, holding constant the distribution of demands. If organizational trade-offs associated with the division of labor do not affect firms' boundaries, then firms' boundaries should not narrow as market size increases and individuals specialize. This is the case when, as depicted in the previous subsection, firms' boundaries merely mirror the distribution of demands of individual demanders. Finding instead that firms' boundaries narrow as individuals specialize is therefore 
evidence that organizational trade-offs associated with the division of labor affect firms' boundaries. ${ }^{9}$

\subsection{Law Firms' Boundaries: The Benefits and Costs of Ex Ante Revenue Sharing}

\section{Arrangements}

Beyond testing whether organizational trade-offs in general affect law firms' scope, our analysis will also provide some evidence with respect to different classes of theories that broadly share the Coasian view.

Regardless of their legal form of organization, law firms in the U.S. are always structured around "ex ante" revenue-sharing arrangements among the firm's partners, i.e. arrangements that are in place before individuals obtain information about specific economic opportunities, and have the feature that all individuals receive some share of revenues from the services any of them supply (although the share the involved individuals receive may be higher). Firms' horizontal scope reflects the fields that partners cover. From the perspective of the partnership, whether a field is covered by the firm is equivalent to whether an individual with expertise in the field is included in the revenue-sharing arrangement. Thus, when discussing the organizational tradeoffs with respect to law firms' scope, we emphasize the benefits and costs associated with ex ante revenue-sharing arrangements. ${ }^{10}$

The production of legal services also involves the use of other resources such as office space, office equipment, libraries, or secretaries. Although scale economies exist with respect to these resources, it common for them to be shared across lawyers in different firms when these resources would be otherwise underutilized. ${ }^{11}$ This feature of the industry suggests that law firms' boundaries are shaped primarily by contractual trade-offs rather than technological tradeoffs, consistent with the view taken by the economics of organization literature. Our analysis

\footnotetext{
${ }^{9}$ The idea that firms' boundaries may narrow as market size increases is not new to industrial organization. It is an implication in Stigler (1951). The Coasian logic discussed here is not part of Stigler's analysis.

${ }_{10}$ We focus on issues that bear on revenue sharing arrangements' effect on firm scope. Revenue sharing arrangements may have other roles as well, such as encouraging the hiring of high-ability individuals (Levin and Tadelis (2002)). Similarly to Holmstrom and Milgrom (1994) and Holmstrom (1999), our account emphasizes how firms can outperform markets by weakening individual incentives. Because the trade-offs we investigate are different, so are our predicted relationships between specialization (job design) and optimal organizational form. We do not address other incentive problems, such as those deriving from the risk of expropriation of specific investments (Klein, et al. (1978)) or to the role of physical assets in providing incentives in the presence of incomplete contracts (Grossman and Hart (1986), Hart and Moore (1990)), which may be more important in other environments.
} 
will thus focus on contractual issues rather than scale or scope economies associated with inputs other than lawyers' human capital.

\section{a. Knowledge Sharing}

An important problem created by specialization is the need for individuals with different expertise to share knowledge. This knowledge could be about the existence of economic opportunities or it could concern expertise relevant to addressing a client's legal problem.

Consider first the problem of sharing knowledge about the existence of an opportunity between lawyers with different expertise. A lawyer who knows that a particular client has a legal problem may conclude that she herself has a comparative advantage in addressing this problem or, alternatively, she may determine that some other lawyer is better qualified to deal with the problem. In the latter case, she must refer it to another lawyer, potentially losing the rents that could be derived from serving the client herself.

This problem was studied by Garicano and Santos (2002). They note that information asymmetries favor those who have private information about opportunities, regardless of whether firms or markets mediate relationships between individuals. Giving away this information is equivalent to giving away rents. As a result, referrals take place under some incomplete information, with an informational asymmetry that favors the referrer. In this context, ex ante revenue sharing arrangements facilitate the exchange of referrals. When firms mediate relationships between individuals, individuals share revenues regardless of who supplies the service. In contrast, when markets mediate such relationships, individuals with private knowledge about an opportunity only share revenues with others if a referral actually takes place. ${ }^{12}$ Individuals' incentives to hold on to problems that others have a comparative advantage in solving are weaker when firms mediate relationships than markets, because they share revenues even when no referral takes place.

\footnotetext{
${ }^{11}$ Results from the Heinz and Nelson survey described below report that most sole practitioners share office space, copying machines, libraries, and other fixed inputs with lawyers in other firms.

${ }^{12}$ Lawyers in different firms are generally allowed to compensate each other for referrals as long as the terms are disclosed to clients. This is unlike the medical profession, in which compensation for referrals is (nominally) prohibited.
} 
Ex ante revenue sharing arrangements effectively tax individuals when they hold on to opportunities themselves, thus weakening their incentives to hold on to opportunities for which they are not best qualified to serve. Thus, one benefit of partnership-like arrangements - the benefit of transacting "within a firm" - is that they improve the efficiency of the exchange of referrals relative to alternative organizational structures.

Specialists not only need to share knowledge about opportunities among each other; they sometimes must also collaborate by sharing substantive knowledge such as legal expertise or knowledge about clients. Again, incentive problems can arise from the exchange of knowledge because when one lawyer shares knowledge with another, he or she gives up informational rents. When lawyers share knowledge with one another, they reduce their future value to clients relative to those with whom they share it.

A similar logic to that proposed by Garicano and Santos explains the advantage of ex ante revenue sharing arrangements in this case. Revenue sharing arrangements facilitate the exchange of knowledge for two reasons. First, the receiver of knowledge shares with the transmitter a share of his future revenues, so that the sender benefits in the future from the more extensive knowledge of the receiver. Second, the sender shares with the receiver his present and future revenues, thus diminishing the extent to which he appropriates returns from his own use of this knowledge. Revenue sharing arrangements increase the extent to which the sender benefits when others use his knowledge relative when he uses it himself.

It follows that lawyers should be more likely to work within the same versus different firms, the more valuable knowledge sharing - referrals or collaboration -- is. Thus, lawyers in fields across which knowledge-sharing is valuable should be more likely to be found within the same firm than those in fields across which knowledge-sharing is less valuable.

\section{b. Risk Sharing}

An alternative view of the benefits of revenue-sharing arrangements is that they facilitate risk sharing among specialists. This is proposed by Gilson and Mnookin (1985). In this view, revenue sharing arrangements insure lawyers against fluctuations in demand for their expertise. It follows that such arrangements would be particularly valuable for lawyers in fields where demands are negatively correlated, and least valuable for lawyers in fields where demands are highly positively correlated.

c. Free Riding and Monitoring 
The general drawback to revenue-sharing arrangements, the drawback to transacting within firms in this context, is that free-rider problems emerge. Individuals do not appropriate the full value of their efforts under such arrangements, and this weakens effort incentives. (Alchian and Demsetz (1972), Holmstrom (1982)) Revenue-sharing arrangements could weaken lawyers' incentives to do high-quality work. The agency costs associated with such arrangements are one reason firms' boundaries might narrow as market size increases and individuals specialize.

Partnerships have other incentive instruments in addition to revenue-sharing arrangements, such as bonuses. If used effectively, these instruments can mitigate free-rider problems to some extent, and thus decrease the cost of transacting within firms. Using these effectively, however, requires that lawyers be able to assess each others' output. Because of this, all of these incentive instruments tend to become less useful as specialization increases, since agents' expertise overlaps less. As lawyers become more specialized, the cost of transacting within firms tends to increase. This would be particularly the case when different lawyers specialize in fields where the fundamental legal doctrines have little overlap (banking law and criminal law, for example), if it is difficult for them to assess each others' work. An implication is that lawyers in fields across which monitoring is more efficient should be more likely to work in the same firm than those across which monitoring is less efficient, since the cost of transacting within firms is lower.

\subsection{Empirical Strategy and Implications}

We provide empirical evidence with respect to whether these sources of variation affect firms' boundaries in two ways. One extends the exercise described above: we analyze how firms' boundaries narrow as market size increases and individuals become more specialized. Specifically, we determine which fields tend to be covered in the same firm as other fields only when they are covered by the same individual - that is, for which specialties the pattern looks

like the top rather than the bottom in Figure 1. Once individuals specialize in these fields, they tend to work in field-specialized firms. Relationships between them and specialists in other fields tend to be mediated by markets, not firms. The other approach simply assesses which pairs of specialists tend to work in the same firm with one another versus not. Unlike the approach described above, this holds individuals' specialization constant, and thus provides no 
evidence on whether changes in the division of labor are associated with changes in firms' boundaries. But it provides additional evidence with respect to the scope of non-specialized firms. Returning to Figure 1, while the first approach could detect whether specialists in field A work in the same firm as specialists in other fields, it could not detect which other fields. Evidence on which specialists work at the same firm as individuals in field A and which do not sheds some light on whether firms' scope corresponds to variation in the value of knowledge sharing, risk sharing, and monitoring costs.

This evidence will be more successful in distinguishing between some explanations than others. In particular, one would expect firms' boundaries to differ sharply, depending on whether they reflect risk-sharing benefits or the other two sources of variation. If firms' boundaries were primarily driven by risk-sharing benefits, one would expect fields that differ sharply in their client base to be more likely to be found within the same firm than fields with similar client bases. This pattern would differ from the pattern one would expect if firms' scope were driven by knowledge sharing or monitoring cost considerations, both of which broadly imply that specialists in unrelated fields should be mediated by markets. Distinguishing between knowledge sharing and monitoring cost explanations is far more difficult, since many patterns that one might expect if firms' boundaries reflect knowledge sharing benefits - for example, that specialists in corporate law are more prone to work at the same firm with specialists in banking law than with specialists in negligence law - could also be explained by variation in monitoring costs.

Our discussion of our empirical evidence will reflect this. We first distinguish between risk-pooling and these other explanations. We then go on to discuss the results of our two empirical exercises in light of knowledge sharing and monitoring cost explanations, and conclude that some version of each of these explanations could explain the main patterns that we uncover. ${ }^{13}$ We will then discuss results from a recent survey taken by John P. Heinz and Robert Nelson as part of a follow-up study to Heinz and Laumann (1982). These results shed light on compensation patterns and the organization of work within law firms, and provide evidence on the role of monitoring and knowledge sharing among law firm partners.

\footnotetext{
${ }^{13}$ Distinguishing among these definitively probably requires direct evidence on how referrals, collaboration, and monitoring differ across combinations of fields, something that our main data source does not provide.
} 


\section{Data}

The data are from the legal services portion of the 1992 Census of Services. Like in other industries, the Census surveys individual establishments in this industry. Forms are sent to all law offices that surpass a size threshold (approximately ten employees) or that are part of multiestablishment firms. In addition, forms are sent to a random sample of smaller offices, where the sampling rate is set to obtain reliable MSA-level estimates. In all, the Census sends survey forms to law offices that account for approximately $80 \%$ of revenues in the industry. Details are in Bureau of the Census (1996). The Census publishes MSA-level estimates derived from this survey in Bureau of the Census (1996). In this paper, we use establishment-level data, which are not publicly available.

Along with standard questions regarding revenues, payroll, and employment, the survey asks law offices industry-specific questions that provide detailed information about the distribution of lawyers across field-defined specialties. (See Appendix 1.) It asks respondents to categorize the lawyers that work in the establishment by their primary field and report how many are in each category: how many lawyers at the establishment specialize in corporate law, for example. When lawyers work in multiple fields, they are classified as "general practitioners." The survey thus provides unusually detailed information about organization and specialization at the establishment level. We use data from 1992 because it is the most recent year for which the Census asks the specialty questions.

In all, the Census received responses to these organizational questions from about 28,000 law offices. We omit from our sample law offices with inconsistent responses for the total number of lawyers; for example, those where the number of lawyers summed across the specialty categories does not equal the number of partners plus the number of associates. Our final sample includes 26,151 law offices and 219,033 lawyers. These constitute about 17\% of law offices and 50\% of privately-practicing lawyers in the United States in 1992.

We merged these data with data from 1992 County Business Patterns. County Business Patterns (CBP) provides county-level information regarding the distribution of employment across industries and the employment size distribution of establishments. We compute employment shares for each of seven major (one-digit) industries (e.g., manufacturing) for each county; although information is available for more detailed industry definitions for many 
counties, the Census withholds more detailed data in many cases because of confidentialityrelated restrictions. ${ }^{14}$ We also compute the share of establishments within various employment size categories in the county, and an estimate of employees per establishment by major sector. We derive the latter by multiplying the size category shares by the midpoints of the employment size categories.

The CBP data thus provide information about the distribution and size of local demand for legal services. The employment shares characterize the local economy, and depict the extent to which local demand for legal services comes from different classes of firms: manufacturing versus financial services, for example. They also depict whether local demanders are small or large firms overall and within sectors. For example, counties where the average establishment size in financial services is large contain the country's most important financial districts. Holding constant employment shares, cross-county differences in total employment pick up differences in the size of local demand for legal services. If the employment shares capture differences in the distribution of local demand well, one can think of increases in total employment, conditional on these shares, as rotations in the demand curve for legal services: proportionate increases in the various legal problems encountered by individuals and businesses located in the county. ${ }^{15}$

Using these variables to capture differences in demand has drawbacks. One important drawback is that while the vast majority of most lawyers' business comes from local demanders, some lawyers serve regional or national markets rather than local ones. If employment differences between the very largest counties and smaller counties understate differences in the demand faced by lawyers in these counties, relationships between specialization and employment size will tend to overstate true relationships between specialization and market size. One would expect this issue to arise particularly for lawyers in multi-office firms, in part because they might serve clients based in all of the regions their firm is located.

We address this in a manner that we describe in the following section. At a narrow level, what we do controls for the possibility that lawyers in multi-office firms may draw clients from

\footnotetext{
${ }^{14}$ We have run specifications with two-digit controls, using imputations for county-sectors for which the Census does not report figures. None of the results differ from those reported below, that use one-digit controls.

${ }^{15}$ Bresnahan and Reiss (1991) use rotations in the demand curve to identify relationships between competitive conduct and entry in concentrated markets. The main issues in this paper - the specialization of individuals and firms' scope - play no role in their analysis.
} 
other markets in which their firm has offices; more broadly, it controls for the possibility that such lawyers draw clients from systematically wider geographic regions than those in singleoffice firms. Our main results primarily reflect relationships between specialization and market size for lawyers in single-office firms, so the market definition issue is largely confined to lawyers in single-office firms. This does not eliminate the issue: some lawyers in single-office firms - particularly those in big cities such as New York and Los Angeles -- may serve broad geographic markets. However, we do not think that this effect is driving our results. As we report below, our main results appear even when looking across relatively small markets, regions where it is unlikely that many lawyers in single-office firms serve many non-local clients.

Another theoretically important drawback is that individuals as well as businesses demand legal services, and employment-based measures may not capture the size and distribution of individual demand well. Better measures of individual demand would be population- rather than employment-based, and demographic variables might capture certain demands well (for example, the demand for probate work should be higher in regions with many elderly residents). We have run specifications that use such controls. While some of the controls do help explain differences cross-market differences in specialization patterns, none of our results of interest - which concern relationships between specialization and market size - change when including these additional controls. ${ }^{16}$

Table 1 contains some summary statistics. The average law office has 3.56 lawyers, and the average firm has 3.65 lawyers, a reminder that the average law firm in the U.S. is a very small, single-establishment enterprise. $71 \%$ of the lawyers in our sample are reported to specialize in one of the Census-defined fields. $37 \%$ of law offices and $28 \%$ of firms are specialized, in the sense that all lawyers in the office or firm specialize in the same field. $28 \%$ of lawyers work in multiestablishment firms, but only $5 \%$ of offices are part of multiestablishment firms. Although only $2 \%$ of the law firms in our sample have multiple locations, those that do are much larger than most single establishment firms.

Table 2 provides a more detailed look at specialization patterns. We report these patterns for each of the Census-defined fields. To facilitate analysis both here and below, we present patterns for groups of fields that differ in the source and timing of demands. "Individual fields"

\footnotetext{
${ }^{16} \mathrm{We}$ do not report these results here because they are very similar to those reported below, and releasing results from multiple, closely related specifications can raise disclosure issues for the Bureau of the Census.
} 
are those where all or nearly all demand comes from individuals; in our data, these include criminal, domestic relations, negligence-plaintiff, and probate. We label the rest of the fields, fields where a substantial part of demand comes from businesses, as "business fields." Within these groups, fields differ according to the timing of demands. We propose that demand for legal services can arise either before a contractual arrangement is agreed upon, when lawyers may be involved in drafting agreements and predicting the contingencies that agreements should address, or after contractual terms are agreed upon and take force, when lawyers may be involved in dispute resolution and litigation. We label these "ex ante" and "ex post" fields respectively. Among the business fields, we classify insurance and negligence-defendant as ex post fields, and the rest as ex ante fields. Expertise in insurance law is generally demanded to assess insurance claims or provide defense for parties covered by insurance. (Abrams (2000)) Expertise in negligence is demanded by defendants in tort-related matters. Among individual fields, we classify probate as ex ante and the rest as ex post. ${ }^{17}$

Survey data confirms these cross-field differences in the source and timing of demands. Table 3 reports results from an extensive interview-based survey ("Chicago Lawyers II") of Chicago lawyers completed in 1995 by Jack Heinz and Bob Nelson of the American Bar Foundation. ${ }^{18}$ Questions in this survey ask privately-practicing lawyers what share of their time they spend on business, non-business organizational (e.g., governmental), and individual clients, and how many days per month they spend in state and Federal court. Days per month in court is a good indicator for the degree to which lawyers provide "ex ante" or "ex post" services. We report the average response by specialty for categories that closely match those defined in the Census data. ${ }^{19}$ The table indicates a sharp break in the share of time lawyers in different fields spend on business clients. Specialists in personal injury (on the plaintiff's side of the bar),

\footnotetext{
${ }^{17} \mathrm{We}$ report these together in Table 2 because there is only one ex ante individual field.

${ }^{18}$ These data were collected as a follow-up project to Heinz and Laumann (1982). Heinz and Nelson surveyed a random sample of Chicago-based lawyers taken from the State of Illinois' lawyer registration records. They collected the data by conducting one-hour interviews with subjects at their offices. In all, 788 lawyers from this random sample were interviewed, 526 of whom were in private practice. See Heinz, et. al. (1998) for more details. We are extremely grateful to Jack Heinz and Bob Nelson for sharing their data.

${ }^{19}$ Even these do not always match perfectly. For example, the Chicago Lawyers II survey does not include a separate category for "insurance law," but the Census data does. Jack Heinz reported to us that he believes that most of those reporting "insurance law" to the Census would classify themselves in the Chicago Lawyers II survey as "personal injury-defendant." Fifteen lawyers in the Chicago Lawyers II report themselves to be specialists in "securities;" these lawyers would probably be classified as "corporate" in the Census data. These lawyers' responses to the time allocation and days in court questions are very similar to the "general corporate" lawyers reported in Table 1.
} 
criminal, divorce, and probate law spend almost all of their time on individual clients. The rest (except specialists in municipal law, which predominantly have governmental clients) spend the majority of their time on business clients. Likewise, personal injury, criminal, and divorce specialists spend more days in court than lawyers in any of the other specialties, consistent with the idea that demands for expertise in these fields tend to be more "ex post" than other fields. Although the number of observations is very low, probate specialists appear to spend less time in court than other specialists that serve individual clients, reflecting that the demand they face tends to be more for "ex ante" services.

The first column of Table 2 reports the share of lawyers in each of the Census fields and groups of fields. $27 \%$ of lawyers specialize in an "ex ante" business field; about a third of these are corporate law specialists. $13 \%$ specialize in an "ex post" business field. $15 \%$ specialize in an individual field; about half of these are classified as "negligence-plaintiff." The second and third columns report the share of lawyers working in specialized offices and firms, by specialty. These figures are very similar because individual offices within large multi-establishment firms are generally not specialized by field: if a multi-establishment firm contains lawyers in different specialties, its offices usually do as well. The final column reports the fraction of specialists that work in specialized firms, by specialty. The notable pattern here is that, with the exception of patent lawyers, ex ante business specialists are less prone to work in a specialized firm than ex post business or individual specialists. Over a third of ex post specialists and nearly half of individual specialists work at specialized firms, but less than $20 \%$ of ex ante specialists do. The lowest fraction among the specialties is for corporate law: only $5 \%$ of corporate law specialists work at firms with only corporate law specialists.

Table 2 thus provides some initial evidence regarding firms' scope. This evidence, however, does not indicate that firms' boundaries are sensitive to the division of labor: the fact that ex post business and individual specialists are more likely to work in field specialized firms than most ex ante business specialists may just reflect differences in the scope of clients' demands. Furthermore, it provides no evidence on the scope of non-specialized firms: with which other lawyers do lawyers in ex ante business specialties work? The following two sections, which present the main empirical analysis in the paper, provide evidence on these fronts. 


\section{Market Size, Specialization, and Organization}

\subsection{Empirical Framework}

The first step in our empirical work examines relationships between market size and the probability that lawyers specialize in one of the Census-defined fields. Our basic empirical framework for examining relationships between market size and individual specialization is simple. Let the probability that lawyer $\mathrm{i}$ in market $\mathrm{j}$ is a specialist of some sort be $\mathrm{p}_{\mathrm{i}}$, where:

$$
p_{i}=f\left(X_{j} \beta_{1}\right)
$$

$X_{j}$ is a vector of observable characteristics of local market $j$ and $\beta_{1}$ is a parameter vector. The coefficient on our proxy for local market size, county employment, will be of particular interest. We interpret variation in this variable, conditional on our controls for the distribution of local demand, as proportionate differences in the demand for the spectrum of services lawyers provide.

Our data are at the level of the law office rather than the lawyer. We thus estimate $\beta_{1}$ using the expression:

$$
s_{k}=f\left(X_{j} \beta_{1}\right)
$$

where $s_{k}$ is the share of lawyers in law office $k$ that are specialists of some sort, weighting each observation by the number of lawyers working at the law office. To make interpreting the coefficient estimates simple, we assume that $\mathrm{f}$ is linear, so:

$$
s_{k}=X_{j} \beta_{1}+\varepsilon_{1 k}
$$

This produces a grouped data analog to the linear probability model; $\beta_{1}$ can thus be interpreted as a probability derivative. It captures reduced-form relationships between specialization shares and market characteristics.

We estimate analogous specifications for particular specialties and for groups of specialties. These, for example, relate market size and composition to the share of lawyers who specialize in corporate law, or in any one of the ex ante business fields.

This specification contains an important assumption concerning market definition: lawyers' specialization decisions reflect only the size and distribution of demand in the area in which their office is located. But as noted above, this assumption is problematic when lawyers work in multi-office firms. If lawyers in multi-office firms serve clients based in other markets 
in which their firm has offices, these lawyers' specialization decisions could reflect the size of demand in these other markets as well as their own.

To account for this, we estimate specifications where our proxy for market size is:

$$
e m p_{j}\left[\frac{\sum_{m} e m p_{m} \delta_{m k}}{e m p_{j}}\right]^{\gamma}
$$

where $e m p_{j}$ is employment in county $\mathrm{j}$ ("local market size"), $\mathrm{m}$ indexes counties, and $\delta_{\mathrm{mk}}$ equals one if office $k$ 's firm has an office in market $\mathrm{m}$ and zero otherwise. The numerator of the bracketed expression can be thought of as "firm-level market size." It is just employment summed across all of the counties where office $k$ 's firm has an office. $\gamma$ is a parameter that indicates the degree to which lawyer specialization reflects local or firm-level market size. If $\gamma=0$, the bracketed expression drops out and only the size of the local market matters; if $\gamma=1$, $e p_{j}$ drops out and lawyer specialization reflects firm-level market size.

Market size enters our empirical specifications in log form. Thus, market size enters these specifications through the expression:

$$
\beta_{1} \ln \left(e m p_{j}\right)-\beta_{1} \gamma \ln \left(\operatorname{share~}_{k j}\right)
$$

where share $_{k j}$ is local market size divided by firm-level market size for office $k$. Note that $\ln \left(\right.$ share $\left._{k j}\right)=0$ for offices in single-office firms. Including $\ln \left(\operatorname{share}_{k j}\right)$ controls for the possibility that lawyers in multi-office firms may base specialization decisions on demand outside of their local market.

Below we present specifications that include and exclude $\ln \left(\right.$ share $\left._{k j}\right)$. None of our estimated relationships between specialization and market size change when doing so, indicating that these estimates are robust to how we define the geographic market for lawyers in multioffice firms. This probably reflects that our results are driven by the nearly three-quarters of lawyers that work in single-office firms, so this issue is irrelevant for the vast majority of our sample.

The second step in our empirical approach estimates specifications that relate the probability that an individual works at a field-specialized law firm to market characteristics. ${ }^{20}$

\footnotetext{
${ }^{20}$ Very few lawyers work in field-specialized offices that are part of non-specialized multi-office firms. Thus, our results and conclusions would be exactly the same if we analyzed relationships between market size and the specialization of law offices rather than firms.
} 
Let $p_{i}^{s f}$ denote the probability that an individual is a specialist and works at a field-specialized firm. ${ }^{21}$ We specify:

$$
p_{i}^{s f}=f\left(X_{j} \beta_{2}\right)
$$

As before, because the unit of observation is the law office rather than individual, we estimate specifications based on the equation:

$$
s_{k}^{s f}=f\left(X_{j} \beta_{2}\right)=X_{j} \beta_{2}+\varepsilon_{2 k}
$$

where $s_{k}^{s f}$ is the share of lawyers at office $k$ who are in a specialized firm and we weight observations by the number of lawyers. Note that $s_{k}^{s f}=0$ if lawyers at office $k$ do not share the same specialty as all other lawyers in their firm and $s_{k}^{s f}=1$ if they do; this is a discrete dependent variable model. As above, we estimate analogous specifications for individual specialties and groups of specialties, and where our proxy for market size reflects both local and firm-level market size.

Combined, $\beta_{1}$ and $\beta_{2}$ depict how much individual specialization increases with market size, and whether increases in the division of labor across individuals take place within or between law firms. They thus provide evidence regarding whether firms' scope merely reflects the scope of individual clients' demands. If $\beta_{1}>0$ and $\beta_{2}=0$, this indicates that although individuals specialize more as market size increases, the share of individuals working in fieldspecialized firms does not. This pattern corresponds to the upper arrow in Figure 1, in which firms' boundaries do not narrow as market size increases and individuals specialize. In contrast, if $\beta_{1}>0$ and $\beta_{2}>0$, this indicates that both the share of individuals who specialize and the share of individuals who work in field-specialized firms increase with market size. This would indicate that sometimes the pattern corresponds to the lower arrow in Figure 1, in which firms' boundaries narrow as market size increases and individuals specialize. When $\beta_{1}>0, \beta_{2} / \beta_{1}$ reflects the degree to which increases in the division of labor are mediated by markets. Finding such a pattern is therefore evidence against the hypothesis that law firms' boundaries reflect only the distribution of clients' demands. It would indicate that firms' boundaries sometimes change

\footnotetext{
${ }^{21}$ Our results are unchanged if we define a specialized firm as one where most of the lawyers (rather than all) share the same specialty, for example as one where $75 \%$ or $90 \%$ do.
} 
with the division of labor, consistent with the view that organizational trade-offs - whether firms or markets best mediate relationships between lawyers - influence law firms' scope. ${ }^{22}$

\subsection{Market Size and Lawyer Specialization}

Table 4 contains results regarding individual specialization and market size. It presents estimates of $\beta_{1}$, the coefficient on $\ln$ (county employment), from twelve different regressions. In the top panel, the dependent variable is $s_{k}$, the share of lawyers at law office $k$ who are specialized in one of the fields described above. In the first column, there are no control variables. $\beta_{1}$ is positive and significant: the share of lawyers who specialize in one of our fields is higher in larger counties. The point estimate indicates that doubling market size is associated with a $9.2 \%$ increase in the share of lawyers who are specialists. Moving from the smallest counties in our sample to the largest changes the predicted share of specialists from about $40 \%$ to about $85 \%$.

Moving to the right, the second column contains results including a set of controls that reflect the composition of the local economy in which the law office is located: sector employment shares, average establishment size by major sector, and a state capital dummy. The estimate of $\beta_{1}$ falls by about $10 \%$ from 0.092 to 0.083 when introducing these controls. ${ }^{23}$ While part of the simple relationship between individual specialization and county employment reflects differences in the composition of demand for legal services between small and large markets, the relationship between market size and specialization remains strong when including these controls. The notable patterns in the controls are that specialization is greater in counties with than without state capitals, and in counties where the average establishment size in construction, manufacturing, transportation/utilities, or financial services is large. Specialization tends to be low in counties where the share of employment in the manufacturing or wholesaling sectors is

\footnotetext{
22 The ratio $\beta_{2} / \beta_{1}$ is an instrumental variables estimate of the effect of lawyer specialization on law firm specialization if county employment is a valid instrument for lawyer specialization. This can be seen by writing the ratio as: $\beta_{2} / \beta_{1}=\left[\partial s_{k}^{s f} / \partial(\ln (\right.$ county employment $\left.))\right] /\left[\partial s_{k} / \partial(\ln (\right.$ county employment $\left.))\right]=\partial s_{k}^{s f} / \partial s_{k}$. This identification strategy requires that market size be related to firms' boundaries only through its effect on lawyers' specialization decisions. In Garicano and Hubbard (2003), we discuss why this assumption is plausible in human capital intensive contexts in light of recent organizational theory. We do not emphasize causal interpretations of $\beta_{2} / \beta_{I}$ in this paper.

${ }^{23}$ We have run various specifications that control for the composition of the local market in various ways - for example, controlling for the size distribution of firms with employment size class shares rather than averages. The coefficient on $\ln$ (county employment) changes little.
} 
low relative to the omitted category, which includes construction and mining. (See Table A1 for the full set of estimates.)

The third column includes $\ln$ (share) in the specification. As outlined above, including this variable accounts for the possibility that lawyers in multi-office firms may base specialization decisions on demand in markets outside of their local area. The estimate of $\beta_{1}$ barely changes when including this variable, indicating that the pattern in the second column is primarily driven by relationships between specialization and market size for lawyers in singleoffice firms. This is not surprising given that most lawyers work in such firms.

The bottom three panels present results from analogous specifications, where the dependent variable is the share of individuals that specialize in ex ante business fields, ex post business fields, and individual fields, respectively. In each of these panels, the estimates of $\beta_{1}$ in the second and third columns are positive, significant, and of about the same magnitude: about $0.020 .^{24}$ Table 5 reports results from 13 additional regressions where the dependent variables are the share of lawyers that specialize in each of the fields in our data. The estimates of $\beta_{1}$ are positive and significant for some of the ex ante business fields and both of the ex post ones. In contrast, the only individual field for which the coefficient is positive and significant is negligence-plaintiff; there is no evidence that the share of lawyers specializing in probate, criminal, or domestic law increases with market size. Indeed, the share specializing in probate and domestic law decreases slightly.

Assuming that changes in our market size measure alter the size but not the distribution of demand for legal services, fields for which the coefficients are positive - banking, corporate, real estate, insurance, and negligence law -- are those that tend to be covered by "general practitioners" in small markets but specialists in large ones.

In sum, our evidence on lawyer specialization is that lawyers specialize more in several business-oriented fields as market size increases, but we find no evidence that this is true for most individual-oriented fields. Increases in specialization with market size reflect that lawyers serving businesses in small markets supply services that usually cross field boundaries, but this becomes less and less true as market size increases. The next section examines whether firm

\footnotetext{
${ }^{24}$ Ln(county employment) ranges from about nine to about fourteen in our data. Hence, the coefficient estimate implies a difference in each of these three specialty shares of about ten percentage points between very small and very large markets.
} 
specialization increases in the same way. In fields in which lawyer specialization increases with market size, this will indicate the degree to which increases in the division of labor take place within or between firms, and provide evidence whether organizational trade-offs affect firms' boundaries.

\subsection{Market Size and the Division of Labor Within and Between Firms}

The first row of Table 6 contains results from regressions that are analogous to those in the middle column of Table 4 , but use $s_{k}^{s f}$ rather than $s_{k}$ as the dependent variable. These regressions relate the share of lawyers working in field-specialized law firms to market size and composition. These relationships are of particular interest for fields in which individual lawyers specialize more with market size. Finding that lawyers become more specialized and work more in field-specialized firms as market size increases indicates circumstances where organizational trade-offs influence firms' boundaries; in these cases, the division of labor tends to be mediated between rather than within firms.

In the first column, the dependent variable is the share of lawyers who work in a fieldspecialized law firm. $\beta_{2}$, the coefficient on $\ln$ (county employment), is positive and significant: as market size increases, a larger share of lawyers works in field-specialized firms. The point estimate is 0.039 , indicating that doubling market size is associated with a 3.9 percentage point increase in the share of lawyers working at specialized firms. This is about one-fourth of the sample mean of $16.2 \%$. The bottom of the table contains the estimates of $\beta_{1}$ from the middle column in Table 4, which track relationships between individual lawyer specialization and market size. The ratio of the point estimates, $\beta_{2} / \beta_{1}$, equals 0.47 , indicating that about half of the overall increase in the division of labor is happening between rather than within firms. This indicates that in some cases, firms' field scope narrows as market size increases, suggesting that firms' boundaries do not merely reflect the distribution of demands. This evidence is consistent with the hypothesis that organizational trade-offs, which appear only when fields are covered by different individuals, influence firms' boundaries.

The other three columns break things down by specialty class as before. In the second column of the top row, the dependent variable is the share of lawyers that work at an office where all lawyers specialize in a single ex ante business field. The coefficient on market size is very small and not statistically significantly different from zero. Table 4 indicated that as market 
size increases, lawyers specialize more in these fields; this result indicates that lawyers are not more likely to work in field-specialized firms. The ratio $\beta_{2} / \beta_{1}$ is approximately zero, indicating that all of the increase in the division of labor is occurring within rather than between firms. In contrast, in the next column of the top row, the dependent variable is the share of lawyers that work at an office where all lawyers specialize in a single ex post business field. Here, the coefficient on market size is positive and significant. From before, as market size increases, more lawyers become insurance and negligence-defendant specialists. Here, we see that a substantial fraction of these specialists work in specialized law firms. The ratio $\beta_{2} / \beta_{1}$ provides an estimate of this fraction: $57 \%$. Like the ex ante business fields, the division of labor increases with market size; unlike the ex ante business fields, a significant fraction of it happens between rather than within firms.

This result indicates that ex post business fields tend only to be covered in the same firm as other fields when they are covered by the same person, but ex ante business fields tend to be covered in the same firm as other fields even when they are covered by different individuals. Assuming that variation in our market size proxy captures differences in the size but not the distribution of demand, demand for services that involve each of these fields of the law exists in smaller markets, but the individuals supplying these services tend not to be specialized. For example, lawyers who advise clients on insurance law issues might also advise clients on corporate and tax law issues. When individual lawyers have multiple specialties, so do firms. As market size increases, lawyers specialize more: different lawyers begin to advise clients on different areas of the law. As lawyers specialize, some specialties remain within the firm and some are spun off: the scope of the firm continues to include corporate and tax law, but it often no longer includes insurance law.

Table 7 provides a more detailed view. The dependent variables in these regressions, analogous to the top panel of Table 6, are the share of lawyers working at firms that specialize in the different fields. The contrast in Table 6 between ex ante and ex post specialties holds in this table as well. None of the coefficient estimates in the first row show statistically significant relationships between market size and the fraction of lawyers working in field-specialized firms. But both of the coefficient estimates in the second row are positive and significant. As market size increases, a greater share of lawyers specializes in both insurance and negligence-defense, and a greater share of lawyers work in offices that specialize in each of these fields. $\beta_{2} / \beta_{1}$ for 
insurance and negligence-defense equals 0.58 and 0.30 , respectively. In contrast, while the division of labor increases with market size for some of the ex ante specialties, there is no strong evidence that much of this is taking place between firms. Firms' boundaries often change once individuals specialize in ex post fields, but there is little evidence that they do once individuals specialize in ex ante fields.

Figures 2 and 3 summarize the general patterns for ex ante and ex post business fields, respectively. The top line in each represents the share of lawyers in a specialized field, and the bottom line represents the share of lawyers working at a field specialized law firm. For the ex ante fields, the distance between the lines increases with market size; an increasing share of lawyers work as specialists but in non-specialized firms. The bottom line is flat. For the ex post fields, the distance between the lines increases somewhat but the bottom line is upward sloping. More lawyers specialize in these fields as market size increases, and an increasing share of lawyers work in specialized firms.

The final column in Table 6 examines relationships between market size and the likelihood an individual works at a firm that specializes in a field that tends to serve individuals. The coefficient is positive and significant, indicating that the share of lawyers working in such firms increases with market size. The coefficient estimate is 0.019 , which is about the same as the analogous estimate in bottom panel. This suggests that as lawyers specialize more in individual fields, the division of labor between them and lawyers in other specialties takes place entirely between firms. Table 7 provides more detail. Recall that the only individual field where we find that individuals specialize more as market size increases is negligence-plaintiff. The coefficient on $\ln$ (county employment) in the negligence-plaintiff column in Table 7 indicates that as market size increases, the share of lawyers working at firms that specialize in this field increases. The ratio $\beta_{2} / \beta_{1}$ equals 0.72 , indicating that most of the increase in the division of labor between negligence-plaintiff specialists and other lawyers is taking place between rather than within firms.

Finally, Table 8 reports estimates of $\beta_{1}$ and $\beta_{2}$ when running the regressions on observations in small and large markets separately. We divide the sample roughly in half, distinguishing between offices in counties with less than and greater than 200,000 employment. ${ }^{25}$

\footnotetext{
${ }^{25}$ Counties with approximately 200,000 employees include Fresno County, CA, and Polk County, IA. The latter is the county in which Des Moines is located.
} 
The main result from this table is that the overall relationships between lawyer and firm specialization and market size in Table 8 appear throughout the range of our sample. ${ }^{26}$

This robustness is of interest for the following reasons. First, as alluded to earlier, it gives us some confidence that our results are not driven by assumptions about market definition. A county-based definition for lawyers' geographic market seems particularly sensible for lawyers in small markets, and our results show up when restricting the analysis to such markets. The other reason concerns the $\beta_{1}$ estimates. One might not expect $\beta_{1}$ to be positive in the bottom panel, since markets with at least 200,000 employees (at least the size Fresno, CA or Des Moines, IA) are probably large enough to support individual specialization in any of the fields in our data. The positive coefficients on $\beta_{1}$ in the bottom panel suggest to us that lawyers specialize along multiple dimensions, including some that are not captured by the Census' categories: for example, for example, by industry. If this is the case, then it is easy to explain why field-based specialization might increase with market size, even when comparing relatively large markets. In medium-sized markets, some lawyers specialize by industry but not field (e.g., they handle corporate and tax work for utilities); as market size increases, they specialize by industry and field. The idea of examining how firms' boundaries change with individual specialization produces interesting results across a surprisingly large range of the data because individuals specialize by field more in larger markets, even when comparing relatively large markets.

\section{The Field Composition of Law Firms}

The previous section analyzed relationships between the division of labor and law firms' scope. This provided evidence that firms' boundaries reflect not just the scope of individual clients' demands, but also organizational trade-offs. However, this exercise provided limited evidence about law firms' field composition. Thus, while it provided evidence that firms' boundaries reflect not just the scope of individual clients' demands but also organizational tradeoffs, it could not provide much evidence on the nature of these trade-offs. This section deepens the previous analysis by providing evidence on which types of specialists tend to work at the

\footnotetext{
${ }^{26}$ One can see this as well using a series of market size dummies rather than $\ln ($ county employment) in the regressions.
} 
same firm with one another and which do not. ${ }^{27}$ We then interpret the patterns in light of the knowledge-sharing, risk-sharing, and monitoring cost hypotheses discussed above.

We develop a statistic that indicates the degree to which lawyers in one field work in the same firm with lawyers in other fields, relative to a benchmark in which the field-shares of lawyers in each firm is the same as the field-shares of lawyers in the economy. ${ }^{28}$ Let $N_{i}$ be the number of lawyers in firm $i$ and $n_{i}^{j}$ be the number of those lawyers who specialize in field $j$. We start by computing the share of field $a$ lawyers in the average field $b$ lawyer's firm. Define this share as $s^{a b}$ :

$$
s^{a b}=\sum \frac{n_{i}^{b}}{\sum n_{i}^{b}} \frac{n_{i}^{a}}{N_{i}}
$$

where all the sums are taken over $i . s^{a b}$ is a weighted average of the share of lawyers in field $a$, where the average is taken across all firms in the economy and the weight for each firm $i$ is the share of $b$ lawyers in the economy who work in firm $i$. We then normalize $s^{a b}$ by the share of lawyers in field $a$ in the economy. Thus for any pair of fields $a$ and $b$, this statistic is:

$$
\Gamma^{a b}=\frac{s^{a b}}{s^{a}}=\frac{1}{s^{a}} \sum \frac{n_{i}^{b}}{\sum n_{i}^{b}} \frac{n_{i}^{a}}{N_{i}}
$$

$\Gamma^{a b}$ is the share of field $a$ lawyers in the average field $b$ lawyer's firm, normalized by $s^{a}$, the share of lawyers in field $a$ in the economy. It is straightforward to show that this statistic is symmetric: i.e. $\Gamma^{a b}=\Gamma^{b a}$.

This statistic is easy to interpret. $\Gamma^{a b}=1$ if the share of field $a$ lawyers in each firm where field $b$ lawyers work is equal to the share of field $a$ lawyers in the economy. If $\Gamma^{a b}>1$, this indicates that most field $b$ lawyers work in firms with high shares of field $a$ lawyers, relative to the share of field $a$ lawyers in the economy. $\Gamma^{a b}=1.30$ indicates the share of field $a$ lawyers in the firm where the average field $b$ lawyer works is 30\% higher than in the population as a whole. $\Gamma^{a b}=0.70$ indicates that it is $30 \%$ lower.

Table 9 presents our results from this approach. We note four important patterns. First, the general pattern with the off-diagonal terms is that ex ante business specialists tend to work at

\footnotetext{
27 See also Phillips and Zuckerman (2000), who analyze the determinants of whether Silicon Valley law firms' scope includes family law.

${ }^{28}$ Previous versions of this paper reported versions of the Ellison-Glaeser statistic (Ellison and Glaeser (1997)), which uses random allocation rather than a uniform distribution as a benchmark. The results are very similar. We report the uniform-benchmarked statistics described here because the magnitudes are more readily interpretable.
} 
the same firm as one another, but most other pairs of specialists tend not to do so. Most of the statistics in the upper left of the figure are greater than one; most in the rest of the figure are less than one. The second and third patterns are the exceptions to this rule. The second is that specialists in patent law, classified as an ex ante business field, tend not to work at the same firm with specialists in other ex ante business fields (or any other field, for that matter). Unlike other ex ante business specialists, patent lawyers tend to work in firms that are field-specialized. The third is that specialists in probate law, an individual field, tend to work in the same firm with ex ante business specialists. In fact, they are more likely to work at the same firm as banking, corporate, environmental, and other ex ante business specialists than other types of individual specialists. This is the exception to the general rule that specialists in business and individualoriented fields tend not to work at the same firm with each other. Last, the diagonal terms are systematically greater than the off-diagonal terms. Some of this is artificial, since part of the high value of the diagonal reflects that specialists always work at firms where the share of their own field is positive - their firm reflects themselves. At the bottom of the table we report statistics for the diagonal terms that do not include this effect; these statistics remain greater than any of the associated off-diagonal terms. Lawyers are more likely to work at the same firm with lawyers in their own field than with lawyers in any other field. This reflects groups of partners and associates in the same field working at the same firm. ${ }^{29}$

Broadly, these patterns provide no support for the hypothesis that law firms' field boundaries strongly reflect the risk-sharing benefits of revenue-sharing arrangements. Lawyers in the same field or fields where demands are closely related tend to work at the same firm more than lawyers in fields where demands are less closely related. Demand for the services supplied by banking, corporate, real estate, and other ex ante business specialists is likely positively correlated, but specialists in these fields tend to work at the same firm with each other.

It is far more difficult to distinguish between knowledge-sharing and monitoring cost explanations of these patterns, and between knowledge-sharing explanations that emphasize referrals and collaboration. The basic problem is that these hypotheses share the feature that the net benefits of transacting within a firm should be higher when fields are closely related in some

\footnotetext{
${ }^{29}$ A next step in our research agenda is to study organizational issues other than law firms' field scope, such as partner-associate ratios and scale within fields. This step would provide further investigate the organization of specialists in the same field.
} 
way. As we explain below, some version of each of these theories could explain the bulk of the patterns in Table 9. Detailed evidence on cross-field referral, collaboration, and monitoring is probably necessary to provide definitive evidence with respect to these hypotheses; we provide some preliminary evidence along these lines in the section that follows.

For example, one explanation of the off-diagonal patterns is that they reflect differences in the value of cross-field referrals. One would expect knowledge-sharing about opportunities to be more valuable across ex ante fields than ex post fields if clients' ability to assess the scope of their legal problem - their ability to self-refer -- differs with the timing of demand. Clients demand ex ante services in anticipation of potential future disputes among parties or conflicts with the law; these problems often potentially can involve many different areas of the law. (Does this deal have important tax implications or create regulatory problems?) Legal expertise is valuable for determining which of these areas are important. In contrast, it tends to be less difficult for clients demanding ex post services to determine the range of relevant legal expertise. The interaction between a client's situation and the law is often clear, even to non-experts. For example, expertise in insurance law is valuable for a company with a complicated insurance claim; expertise in torts is valuable to a company being sued for negligence. While legal expertise is generally valuable for such clients, referrals across specialists in different areas of the law tend not to be because the scope of most clients' legal problems is well-defined at this point in contractual time. If this is true, this could explain why lawyers in ex ante fields tend to work in the same firm with each other, while lawyers in ex post fields tend to work in fieldspecialized firms. It could also explain the exceptions to the general empirical pattern. Patent law is fairly distinct from other areas of the law, and is probably an exception to the rule that clients have difficulty judging the scope of services they need for ex ante problems. Referrals between ex ante business specialists and probate lawyers may be valuable, as when the senior management of corporate clients need help arranging wills and estates.

Alternatively, most of these patterns could reflect differences in the value of knowledgesharing in collaboration or in monitoring costs. The value of sharing legal expertise or client knowledge may be systematically greater across ex ante business fields than between these and other fields, and one can construct plausible explanations for why patent and probate law are exceptions. Variation in monitoring costs could also explain this general pattern, especially if ex ante business fields (except patent law) are conceptually close to one another. However, we do 
not believe that the monitoring cost hypothesis provides a convincing story of why probate lawyers work at the same firms with other ex ante specialists. It is unlikely that, for example, corporate lawyers and probate lawyers have a comparative advantage in assessing each others' work because the conceptual connections between probate law and other ex ante fields are weak. An indication of this is provided by the finding in Heinz and Laumann (1982) that nonspecialized individuals who do probate work very rarely also do work in corporate law or other business fields.

Likewise, any of these hypotheses can explain why lawyers in the same field tend to work with one another in the same firm more than lawyers in different fields. This empirical finding could reflect that the value of collaboration is high or monitoring costs are low when lawyers work in the same field. It could also reflect that referrals tend to be valuable within fields; revenue-sharing arrangements may help encourage lawyers who are overloaded with work to refer them on to others with similar expertise.

We next turn to survey evidence, which will provide some more detailed data about compensation and collaboration patterns within law firms. These data provide evidence on revenue-sharing arrangements' objectives. We view this evidence as a first step in sorting out these knowledge-based and monitoring cost explanations of law firms' boundaries.

\section{Survey Evidence}

Table 10 contains additional evidence from the Chicago Lawyers II survey described above. Law firm partners were asked: "How important are each of these factors in decisions regarding the division of the profits of the firm?" The table contains the share of partners reporting "very important" and "important" for each of seven factors. Most partners in this survey report that "bringing in new business," "hours billed," and "client ties" are either important or very important. Other factors are important far less frequently. For example, only $38 \%$ of partners report that a senior partner's decision is important or very important, and an

even lower share report that personal favoritism is. Few partners report that seniority is 
important, indicating that "lock-step" compensation methods, where all partners where equal seniority share equally in the income of the firm, are rare. ${ }^{30}$

We draw two inferences from this table. First, encouraging referrals is an important organizational objective addressed by revenue-sharing arrangements. While a simple revenuesharing arrangement would accomplish this to some degree, basing revenue shares on business generation as well as hours billed accentuates this. This provides support for the hypothesis that a benefit of transacting within firms has to do with knowledge-sharing about opportunities.

Second, partners' assessments of each others' work generally does not affect their compensation directly. If firms commonly base profit shares directly on such assessments, one would expect more partners to report that their firms divide profits on the basis of subjective factors such as senior partners' decisions (and perhaps personal favoritism). Note, however, that this evidence does not imply that one can reject the monitoring cost hypothesis outright; the table provides no direct evidence on monitoring, and only provides evidence on one particular incentive instrument. Variation in monitoring costs may affect law firms' boundaries, but if within-firm monitoring is important, it must support incentive instruments that do not directly affect how revenues are shared. For example, lawyers who are perceived by others in their firm to do high quality work may be rewarded via greater demand for their services - they receive more referrals from others in their firm -- or those who are perceived to do low quality work may be more likely to be asked to leave the firm.

The Chicago Lawyers II survey also sheds some light on how frequently partners collaborate with each other. It asks lawyers working in firms with at least five lawyers how frequently they work with lawyers at the same level or at levels above them. As Table 11 shows, of the 182 partners answering the question, 34 report that they seldom or never work with others at the same or higher levels. ${ }^{31}$ This strongly suggests that while most partners in this survey collaborate with other partners at least occasionally, a substantial fraction does not. One explanation would be that partners who do not collaborate with other partners work in very small firms or departments. However, as depicted in the table, these respondents work in large

\footnotetext{
${ }^{30}$ Cotterman (1995) reports that only a small number of firms employ lock-step methods, although this group includes some prestigious law firms, such as Cravath, Swaine, and Moore; Cleary, Gottlieb, Stein, Hamilton; and Covington and Burling.
} 
divisions of large, multi-divisional law firms: on average, they are in divisions with 22 partners and firms with 79 partners. Moreover, partners who do not collaborate with other partners report similar revenue sharing arrangements to those that do collaborate. ${ }^{32}$

It is not unusual for revenue sharing arrangements to include partners who rarely collaborate with any other partner in their firm, and there is no evidence that how revenues are shared differs for lawyers who do and do not collaborate. Revenue-sharing arrangements' role extends beyond facilitating the exchange of substantive or client knowledge, since lawyers who rarely collaborate with any other partner in their firm nevertheless take part in such arrangements.

\section{Conclusion}

Economists have long recognized that economic activity is organized, in part, to exploit increasing returns. For example, a large literature in industrial organization analyzes relationships between industry structure and scale economies; these economies are generally depicted as arising from fixed costs associated with physical capital. But physical capital is not the only source of increasing returns that can affect how production is organized into firms. Rosen (1983) emphasizes that there are increasing returns to human capital, as the cost of learning a skill is independent of its subsequent utilization rate. It follows that the organization of industries where production is knowledge-intensive should reflect problems associated with exploiting returns to human capital specialization. That is, it should reflect trade-offs that have traditionally been examined in the economics of organizations literature starting with Coase (1937) rather than the industry structure literature.

This paper provides new empirical evidence on how one human-capital-intensive industry, legal services, is organized. Our evidence indicates that organizational trade-offs affect firms' field scope: firms' field scope tends to narrow as market size increases and lawyers specialize. Moreover, this pattern varies across fields. As market size increases, the division of labor between lawyers in fields involved in structuring transactions tends be mediated within

\footnotetext{
${ }^{31}$ While some of these may be their firm's highest-ranked partner, it is unlikely that many of them are. One third of these lawyers work at firms with one class of partners, and two thirds report that they have never served on their firm's management committee.
} 
firms. In this segment of the market, firms' scope does not narrow as market size increases. In contrast, the division of labor between lawyers in fields involved in dispute resolution and litigation and lawyers in other fields tends to be mediated by markets. Firms' boundaries narrow with market size as individuals become more specialized; in larger markets, these services tend to be supplied by lawyers in field-specialized firms. These and other patterns are inconsistent with the hypothesis that firms' field boundaries reflect variation in the benefits of risk-sharing, and are consistent with the hypotheses that they reflect variation in the value of knowledgesharing or in monitoring costs. Additional evidence confirms the importance of knowledgesharing about opportunities within law firms.

These findings have implications for the industry structure. Two notable features of the legal services industry in the United States are that the average firm size is small, and that the size distribution of firms is highly skewed: even within large markets, the largest firms have many times more lawyers than the median firm. Our findings suggest that the incentive tradeoffs associated with exploiting increasing returns from specialization in this industry differ across fields, and help lead the structure of the industry to be fragmented, but highly-skewed. The fragmentation results from the fact that, for the reasons we discuss above, the division of labor between lawyers in different fields is usually best mediated by markets. The skewness in part reflects that relationships between lawyers in ex ante fields such as corporate, tax, and real estate law are often best mediated by firms. Future research is needed to investigate how the organizational trade-offs that shape the structure of the legal services industry - including those associated with knowledge sharing and monitoring - influence the structure of other humancapital-intensive industries.

\footnotetext{
${ }^{32}$ One cannot reject the null that lawyers' reports of these structures are the same across these categories, using chisquared tests of any conventional size. The details of how lawyers are compensated may, of course, differ. We have also checked whether specialization patterns differ across these categories and find no evidence that they do.
} 


\section{References}

Abrams, Lisa L. The Official Guide to Legal Specialties, Barbri, Chicago, 2000.

Alchian, Armen A., and Harold Demsetz. "Production, Information Costs, and Economic Organization.” American Economic Review, 62 (1972), 777-795.

Bresnahan, Timothy F., and Peter C. Reiss. "Entry and Competition in Concentrated Markets." Journal of Political Economy, 99 (1991), pp. 977-1009.

Bureau of the Census. 1992 Census of Service Industries: Miscellaneous Subjects, Washington, G.P.O., 1996.

Coase, R. H. "The Nature of the Firm.” Economica, 4 (1937), pp. 386-405.

Cotterman, J. D. ed. Compensation Plans for Law Firms, Altman, Weil, Pensa Inc. (1995), Newton Square, PA.

Ellison, Glenn and Edward L. Glaeser, "Geographic Concentration in U.S. Manufacturing Industries: A Dartboard Approach," Journal of Political Economy, 105 (1997), pp. 889-927.

Garicano, Luis, and Thomas N. Hubbard. "Firms' Boundaries and the Division of Labor: Empirical Strategies," Journal of the European Economic Association, forthcoming, 2003.

Garicano, Luis, and Jesus Santos. "Referrals," University of Chicago, July 2002.

Gilson, Ronald J. and Robert Mnookin. "Sharing Among the Human Capitalists: An Economic Inquiry into the Corporate Law Firm and How Partners Split Profits," 37 Stanford Law Review 313 (1985). 
Glaeser, Edward, Hedi D. Kallal, Jose A. Scheinkman and Andrei Shleifer "Growth in Cities”, Journal of Political Economy, 100 (1992), pp. 1126-52.

Grossman, Sanford J., and Oliver D. Hart. "The Costs and Benefits of Ownership: A Theory of Vertical and Lateral Integration," Journal of Political Economy, Vol. 94 (1986), pp. 691-719.

Hart, Oliver and John Moore. "Property Rights and the Nature of the Firm", Journal of Political Economy, 98 (1990), 1119-58.

Heinz, John P., and Edward O. Laumann. Chicago Lawyers: The Social Structure of the Bar, Evanston, Northwestern University Press, 1982.

Heinz, John P., Edward O. Laumann, Robert L. Nelson, and Ethan Michelson. "The Changing Character of Lawyers' Work: Chicago in 1975 and 1995," Law and Society Review, 32 (1998), 751-775.

Holmstrom, Bengt. "Moral Hazard in Teams.” Bell Journal of Economics, 13 (1982), pp 324-340.

Holmstrom, Bengt. "The Firm as a Subeconomy." Journal of Law, Economics, and Organization, 15 (1999), 74-102.

Holmstrom, Bengt and Paul Milgrom “"Multi-Task Principal-Agent Problems: Incentive Contracts, Asset Ownership and Job Design." Journal of Law, Economics and Organization, 7, (1991).

Holmstrom, Bengt, and Paul Milgrom. "The Firm as an Incentive System," American Economic Review, 84 (1994), pp. 972-991. 
Hubbard, Thomas N. "Contractual Form and Market Thickness in Trucking," Rand Journal of Economics, 32 (2001), pp. 369-386.

Klein, Benjamin, Robert G. Crawford, and Armen A. Alchian. "Vertical Integration, Appropriable Rents, and the Competitive Contracting Process," Journal of Law and Economics, 21 (1978), pp. 297-326.

Klemperer, Paul. "Equilibrium Product Lines: Competing Head-to-Head May Be Less Competitive." American Economic Review, 82 (1992), pp. 740-755.

Klemperer, Paul, and A. Jorge Padilla. 'Do Firms' Product Lines Include Too Many Varieties?" Rand Journal of Economics, 28 (1997), pp. 472-488.

Levin, Jonathan and Steven Tadelis. "A Theory of Partnerships," Stanford University, 2002.

Lucas, R. E., Jr. and Esteban Rossi-Hansberg. "On the Internal Structure of Cities," Econometrica, 70 (1992), 1445-1476.

Olsen,Trond E. and Gaute Torsvik "Discretion and Incentives in Organizations", Journal of Labor Economics, vol. 18, No. 3. (Jul., 2000), pp. 377-404.

Phillips, Damon, and Ezra Zuckerman. "Middle-Status Conformity: Theoretical Restatement and Empirical Demonstration in Two Markets," University of Chicago, 2000.

Porter, Michael E. Competitive Advantage. New York, Free Press, 1985.

Romer, Paul, Increasing Returns and Long Run Growth," Journal of Political Economy 94 (1986), pp. 1002-37. 
Romer, Paul. "Growth Based on Increasing Returns Due to Specialization" American Economic Review, 77 (1987), pp 56-62.

Rosen, Sherwin. "Specialization and Human Capital," Journal of Labor Economics, 1, (1983) pp. 43-49.

Stigler, George J. "The Division of Labor is Limited by the Extent of the Market," Journal of Political Economy, 59 (1951), pp. 185-193.

Sutton, John. Sunk Costs and Market Structure: Price Competition, Advertising, and the Evolution of Concentration, MIT Press, 1991.

Sutton, John. Technology and Market Structure: Theory and History, MIT Press, Cambridge, 1998.

Young, Allyn A. "Increasing Returns and Economic Progress," Economic Journal, 38 (1928), pp. 527-42. 


\section{Table 1}

\section{Summary Statistics -- Lawyers, Law Offices, and Law Firms}

$\begin{array}{lccc} & \text { Lawyers } & \text { Offices } & \text { Firms } \\ \text { N } & 219033 & 26151 & 23465 \\ \text { Average Number of Lawyers } & & 3.56 & 3.65 \\ & & & \\ \text { Share Specialized } & 0.71 & 0.37 & 0.28 \\ \text { Share Multiestablishment } & 0.28 & 0.05 & 0.02\end{array}$

Averages and shares computed using sampling weights supplied by the Bureau of the Census. 
Table 2

Shares of Lawyers in Specialized Fields, Offices, and Firms

\author{
Share of Lawyers \\ In Specialized Fields
}

Share of Lawyers

In Specialized Firms

0.044

0.005

0.004

0.001

0.002

0.014

0.013

0.005

0.044

0.023

0.018

0.025
0.018

0.061

0.155

0.158

0.024

0.026

0.074

0.035

0.289

\section{Criminal \\ Negligence-Plaintiff \\ Probate}

General Practice

All shares computed using Census-provided sampling weights.

Fraction of Specialists In Specialized Firms
$17.4 \%$
$12.9 \%$
$4.8 \%$
$6.2 \%$
$13.7 \%$
$70.4 \%$
$22.7 \%$
$17.9 \%$
$34.5 \%$
$40.8 \%$
$27.2 \%$
$44.9 \%$
$49.7 \%$
$34.8 \%$
$57.1 \%$
$23.1 \%$ 


\section{Table 3}

Share of Time on Business Clients, Days per Month in State or Federal Court

Selected Specialties

\begin{tabular}{|c|c|c|c|}
\hline Specialty & $\begin{array}{c}\text { Share of Time } \\
\text { Business Clients } \\
\text { (percent) }\end{array}$ & $\begin{array}{c}\text { Days per Month } \\
\text { In State or Federal } \\
\text { Court }\end{array}$ & $\mathrm{N}$ \\
\hline Commercial Law: Banking & 91.3 & 6.4 & 8 \\
\hline General Corporate & 86.1 & 1.8 & 12 \\
\hline Municipal Law & 35.6 & 0.5 & 6 \\
\hline Environmental Law & 82.3 & 2.8 & 12 \\
\hline Real Estate & 69.9 & 2.9 & 43 \\
\hline Tax & 64.7 & 1.3 & 32 \\
\hline Patents, Trademarks or Copyrights & 89.8 & 2.0 & 25 \\
\hline Personal Injury -- Defendant & 88.3 & 11.6 & 20 \\
\hline Personal Injury -- Plaintiff & 7.6 & 13.9 & 16 \\
\hline Criminal & 10.0 & 16.7 & 9 \\
\hline Divorce (including family, adoption, etc.) & 8.0 & 16.7 & 7 \\
\hline Probate (wills and trusts) & 3.8 & 6.0 & 4 \\
\hline
\end{tabular}

Source: Chicago Lawyers II survey.

Specialty categories are as listed on Chicago Lawyers II survey forms. 


\section{Table 4}

\section{Market Size and Lawyer Specialization}

Estimates of Beta1 in Individual Specialization Regressions

Dependent Variable

\begin{tabular}{|c|c|c|c|}
\hline Share Any Specialty & $\begin{array}{c}0.092 \\
(0.002)\end{array}$ & $\begin{array}{c}0.083 \\
(0.003)\end{array}$ & $\begin{array}{c}0.084 \\
(0.003)\end{array}$ \\
\hline Share Ex Ante Specialty & $\begin{array}{c}0.050 \\
(0.001)\end{array}$ & $\begin{array}{c}0.020 \\
(0.002)\end{array}$ & $\begin{array}{c}0.022 \\
(0.002)\end{array}$ \\
\hline Share Ex Post Specialty & $\begin{array}{c}0.014 \\
(0.001)\end{array}$ & $\begin{array}{c}0.021 \\
(0.002)\end{array}$ & $\begin{array}{c}0.021 \\
(0.002)\end{array}$ \\
\hline Share Individual Specialty & $\begin{array}{c}-0.008 \\
(0.001)\end{array}$ & $\begin{array}{c}0.017 \\
(0.002)\end{array}$ & $\begin{array}{c}0.016 \\
(0.002)\end{array}$ \\
\hline
\end{tabular}

\section{Controls}

Employment Shares in Major Sectors

$\mathrm{N}$

Avg. Estab. Size in Major Sectors

$\operatorname{Ln}($ Share)
$\mathrm{N}$

$\mathrm{N}$

$\begin{array}{ll}Y & Y \\ Y & Y \\ N & Y\end{array}$

Table contains estimates of the coefficient on $\ln$ (county employment) in 12 different regressions.

$\mathrm{N}=26130$ 


\section{Table 5}

\section{Market Size and Lawyer Specialization}

\begin{tabular}{|c|c|c|c|c|c|c|c|}
\hline Dependent Variable & $\begin{array}{l}\text { Share } \\
\text { Banking }\end{array}$ & $\begin{array}{c}\text { Share } \\
\text { Corporate }\end{array}$ & $\begin{array}{l}\text { Share } \\
\text { Environmental }\end{array}$ & $\begin{array}{c}\text { Share } \\
\text { Governmental }\end{array}$ & $\begin{array}{l}\text { Share } \\
\text { Patent }\end{array}$ & $\begin{array}{c}\text { Share } \\
\text { Real Estate }\end{array}$ & $\begin{array}{c}\text { Share } \\
\text { Tax }\end{array}$ \\
\hline In(county employment) & $\begin{array}{c}0.008 \\
(0.001)\end{array}$ & $\begin{array}{c}0.005 \\
(0.001)\end{array}$ & $\begin{array}{c}0.000 \\
(0.000)\end{array}$ & $\begin{array}{l}-0.001 \\
(0.001)\end{array}$ & $\begin{array}{l}-0.001 \\
(0.001)\end{array}$ & $\begin{array}{c}0.010 \\
(0.001)\end{array}$ & $\begin{array}{r}0.000 \\
(0.001)\end{array}$ \\
\hline
\end{tabular}

Ex Post Business Specialties

$\begin{array}{lcc}\text { Dependent Variable } & \begin{array}{c}\text { Share } \\ \text { Insurance }\end{array} & \begin{array}{c}\text { Share } \\ \text { Negligence-Def }\end{array} \\ & & \\ \text { In(county employment) } & \mathbf{0 . 0 1 5} & \mathbf{0 . 0 0 6} \\ & \mathbf{( 0 . 0 0 1 )} & \mathbf{( 0 . 0 0 1 )}\end{array}$

Individual Specialties

$\begin{array}{lcccc}\text { Dependent Variable } & \begin{array}{c}\text { Share } \\ \text { Criminal }\end{array} & \begin{array}{c}\text { Share } \\ \text { Domestic Rel. }\end{array} & \begin{array}{c}\text { Share } \\ \text { Negligence-Pla }\end{array} & \begin{array}{c}\text { Share } \\ \text { Probate }\end{array} \\ \text { In(county employment) } & 0.001 & -\mathbf{0 . 0 0 2} & \mathbf{0 . 0 2 2} & \mathbf{- 0 . 0 0 4} \\ & (0.001) & \mathbf{( 0 . 0 0 1 )} & \mathbf{( 0 . 0 0 2 )} & \mathbf{( 0 . 0 0 1 )}\end{array}$

$\mathrm{N}=26151$

All regressions contain segment shares, average employment size within segments, state capital as controls. 


\section{Table 6}

\section{Market Size, Lawyer, and Law Firm Specialization}

$\begin{array}{lcccc} & \text { Share } & \text { Share } & \text { Share } & \text { Share } \\ \text { Dependent Variable } & \text { Any Specialty } & \text { Ex Ante } & \text { Ex Post } & \text { Individual } \\ & & \text { Business Specialty } & \text { Business Specialty } & \text { Speciality }\end{array}$

Market Size and Law Firm Specialization Regressions (Beta2)

In(county employment)

$\begin{array}{cc}0.039 & 0.000 \\ (0.003) & (0.002)\end{array}$

0.012

0.019

Market Size and Individual Specialization Regressions (Beta1)

$\ln ($ county employment)

0.083

0.020

$(0.002)$

0.021

(0.002)

0.017

(0.003)

$-0.02$

(0.002)

(0.002)

Beta2/Beta1

0.47

$-0.02$

0.57

1.12

Controls include share of employment in 7 major sectors, average establishment size within each of these sectors, and a state capital dummy 
Table 7

\section{Market Size and Law Firm Specialization}

Estimates of Beta2, by Specialty

Ex Ante Business Specialties

Share

Dependent Variable Banking

Share

Share

Share

Share

Corporate

Environmental

Governmental

Patent

Share

Real Estate

Share

In(county employment)

0.000

0.001

(0.001)

0.000

0.000

$-0.001$

$(0.000)$

(0.001)

0.002

(0.001)

$-0.001$

(0.001)

Ex Post Business Specialties

Dependent Variable

Share

Share

In(county employment)

Insurance

Negligence-Def

$\begin{array}{cc}0.009 & 0.003 \\ (0.001) & (0.001)\end{array}$

Individual Specialties

Dependent Variable

Share

Criminal

Share

Domestic Rel.

Share

Share

In(county employment)

0.003
$(0.001)$

0.001

(0.001)

Negligence-Pla

Probate

0.016

$(0.001)$

$-0.001$

$(0.001)$

$\mathrm{N}=26151$

All regressions contain segment shares, average employment size within segments, state capital as controls. 


\section{Table 8}

\section{Market Size, Lawyer, and Law Firm Specialization}

Small and Large Markets

$\begin{array}{ccccc} & \text { Share } & \text { Share } & \text { Share } & \text { Share } \\ \text { Dependent Variable } & \text { Any Specialty } & \text { Ex Ante } & \text { Ex Post } & \text { Individual } \\ & & \text { Business Specialty } & \text { Business Specialty } & \text { Speciality }\end{array}$

Small Markets Only (counties with employment less than 200,000)

$\begin{array}{ccccc}\text { Beta2 } & 0.051 & -0.010 & 0.012 & 0.032 \\ & (0.005) & (0.002) & (0.002) & (0.003) \\ \text { Beta1 } & & & 0.031 & 0.046 \\ & 0.113 & 0.020 & (0.003) & (0.004)\end{array}$

Large Markets Only (counties with employment greater than 200,000)

$\begin{array}{ccccc}\text { Beta2 } & \mathbf{0 . 0 2 6} & -0.004 & \mathbf{0 . 0 1 1} & \mathbf{0 . 0 2 3} \\ & \mathbf{( 0 . 0 0 6 )} & (0.003) & (\mathbf{0 . 0 0 3}) & (\mathbf{0 . 0 0 3 )} \\ \text { Beta1 } & & & & \\ & \mathbf{0 . 0 8 4} & \mathbf{0 . 0 2 2} & \mathbf{0 . 0 2 0} & \mathbf{0 . 0 1 8} \\ & (\mathbf{0 . 0 0 5 )} & \mathbf{( 0 . 0 0 4 )} & \mathbf{( 0 . 0 0 4 )} & (\mathbf{0 . 0 0 4 )}\end{array}$

Beta1 is the coefficient on In(county employment) in regressions where the dependent variable is the share of individuals who are specialized.

Beta2 is the coefficient on $\ln$ (county employment) in regressions where the dependent variable is the share of individuals who work in field-specialized firms.

Controls include share of employment in 7 major sectors, average establishment size within each of these sectors, and a state capital dummy 


\section{Table 9}

\section{Normalized Composition of Law Firms}

By Specialty of the Lawyer

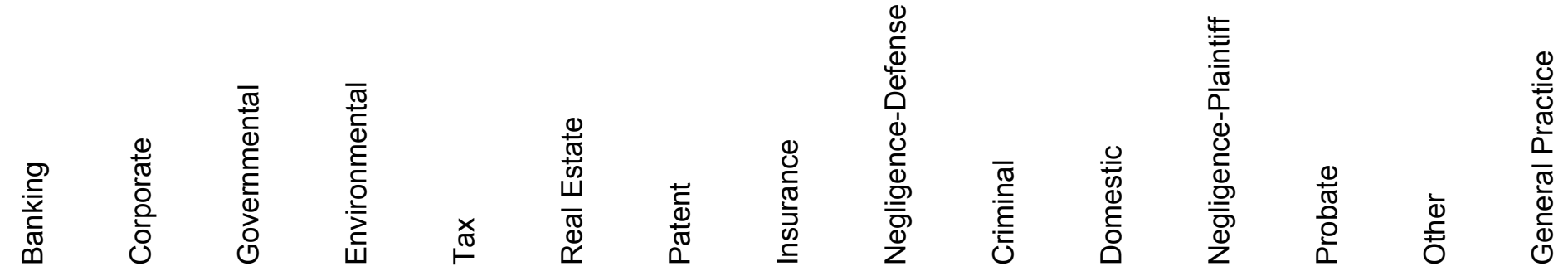

\begin{tabular}{|c|c|c|c|c|c|c|c|c|c|c|c|c|c|c|c|}
\hline Banking & 7.52 & & & & & & & & & & & & & & \\
\hline Corporate & 1.27 & 4.42 & & & & & & & & & & & & & \\
\hline Government & 1.06 & 1.26 & 24.28 & & & & & & & & & & & & \\
\hline Environmental & 1.34 & 1.50 & 2.36 & 13.61 & & & & & & & & & & & \\
\hline Tax & 1.18 & 1.84 & 1.13 & 1.39 & 10.90 & & & & & & & & & & \\
\hline Real Estate & 1.44 & 1.18 & 0.85 & 0.96 & 1.07 & 6.79 & & & & & & & & & \\
\hline Patent & 0.35 & 0.63 & 0.42 & 0.62 & 0.53 & 0.25 & 39.05 & & & & & & & & \\
\hline Insurance & 0.61 & 0.50 & 0.56 & 0.99 & 0.37 & 0.35 & 0.01 & 11.75 & & & & & & & \\
\hline Neg-Def & 0.73 & 0.65 & 0.71 & 1.04 & 0.60 & 0.54 & 0.17 & 0.58 & 9.83 & & & & & & \\
\hline Criminal & 0.33 & 0.48 & 0.47 & 0.44 & 0.41 & 0.49 & 0.07 & 0.19 & 0.19 & 26.97 & & & & & \\
\hline Domestic & 0.61 & 0.49 & 0.80 & 0.47 & 0.40 & 0.74 & 0.07 & 0.30 & 0.33 & 1.61 & 20.80 & & & & \\
\hline Neg-Pla & 0.64 & 0.31 & 0.37 & 0.26 & 0.22 & 0.60 & 0.05 & 0.14 & 0.37 & 0.84 & 0.78 & 10.03 & & & \\
\hline Probate & 0.97 & 1.12 & 0.81 & 0.86 & 1.62 & 1.27 & 0.22 & 0.52 & 0.64 & 0.59 & 1.10 & 0.43 & 11.31 & & \\
\hline Other & 0.65 & 1.05 & 0.73 & 1.02 & 0.89 & 0.68 & 0.31 & 0.23 & 0.26 & 0.28 & 0.38 & 0.18 & 0.53 & 4.20 & \\
\hline Gen Prac & 0.30 & 0.25 & 0.29 & 0.31 & 0.27 & 0.25 & 0.09 & 0.12 & 0.15 & 0.16 & 0.29 & 0.13 & 0.29 & 0.18 & 2.95 \\
\hline $\begin{array}{l}\text { Diagonal } \\
\text { (colleaques only) }\end{array}$ & 4.47 & 3.48 & 13.93 & 10.38 & 3.73 & 2.63 & 32.62 & 9.95 & 8.23 & 6.43 & 5.95 & 4.50 & 3.02 & 2.83 & 1.38 \\
\hline
\end{tabular}

Bold indicates values greater than 1.00 . 


\section{Table 10}

\section{How Are Profits Divided Within Law Firms?}

Partners Only

\begin{tabular}{|c|c|c|}
\hline Factor & $\begin{array}{c}\text { Share } \\
\text { Very Important }\end{array}$ & $\begin{array}{c}\text { Share } \\
\text { Important }\end{array}$ \\
\hline
\end{tabular}

Bringing In New Business

52.3

26.7

29.5

Client Ties

Seniority

Decision of a Senior Partner

Area of Practice

Personal Favoritism
8.2

10.6

2.4

2.4
38.6

58.5

54.9

31.9

27.6

28.0

17.5
90.9

85.2

84.4

40.1

38.2

30.4

19.9

Source: Chicago Lawyers II survey.

Question was asked of 176 partners of Chicago law firms with five or more lawyers. 


\title{
Table 11
}

\section{Work Patterns and Organizational Characteristics}

Partners Only

\author{
Seldom or Never All Others \\ Work with Others \\ At or Clearly Above \\ Their Level
}

$\mathrm{N}$

$34 \quad 148$

Average Department Size

$43 \quad 37$

Partners

Associates

$22-18$

$21 \quad 19$

Average Firm Size

Partners

$\begin{array}{cc}192 & 148 \\ 79 & 71 \\ 113 & 77\end{array}$

Firm Divided Into Departments?

73.5

71.4

Share Reporting that Factor Is Very Important or Important in How Profits of Firm Are Divided (percent)

$\begin{array}{lll}\text { Bringing In New Business } & 91.2 & 91.5 \\ \text { Hours Billed } & 85.3 & 85.6 \\ \text { Client Ties } & 88.2 & 83.3 \\ \text { Seniority } & 45.5 & 54.4 \\ \text { Decision of a Senior Partner } & 29.4 & 40.8 \\ \text { Area of Practice } & 38.2 & 28.6 \\ \text { Personal Favoritism } & 33.3 & 16.7\end{array}$

Source: Chicago Lawyers II survey.

Differences in shares at the bottom of the table are not statistically significant, using a

chi-squared test of size 0.05 . 
Figure 1

Specialization and Organizational Trade-Offs

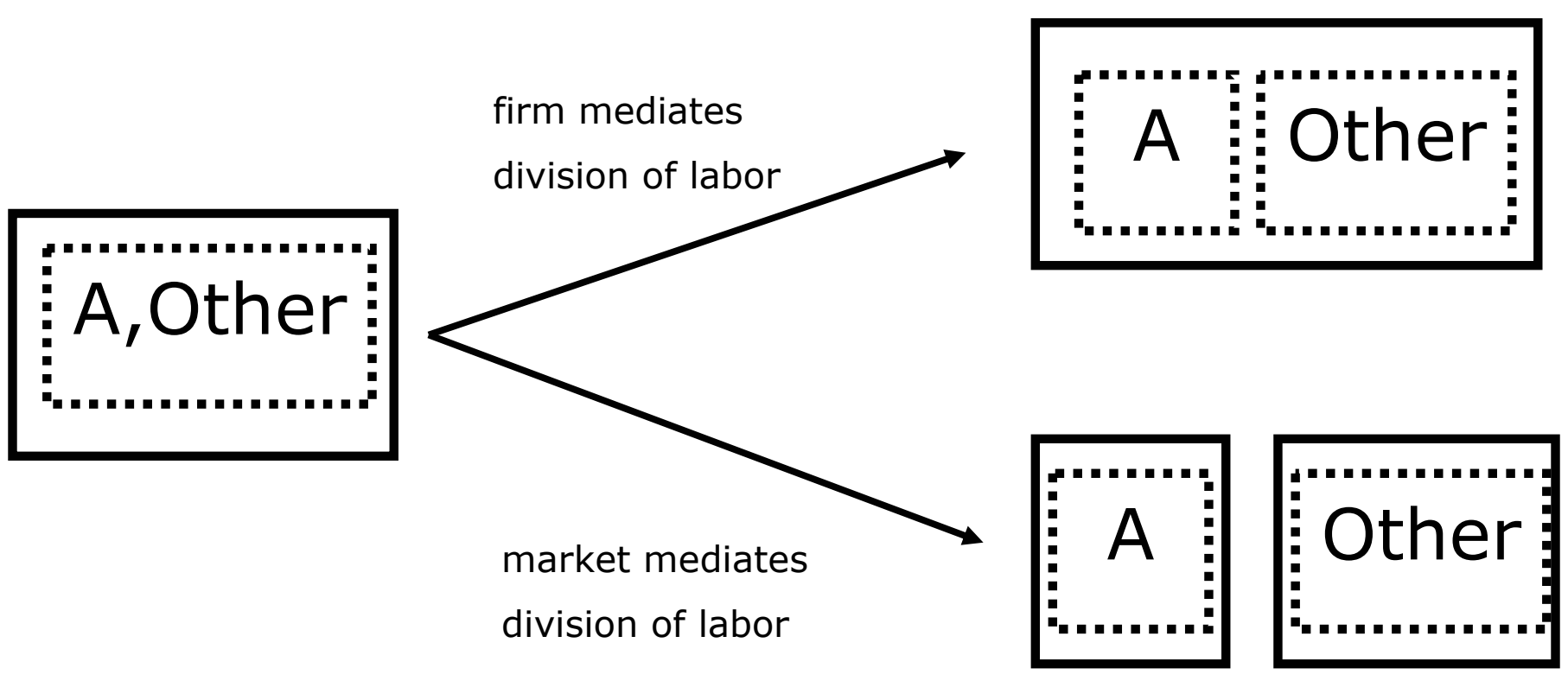

Market Size Increases 

Figure 2

Share of Lawyers in Specialized Fields, Field Specialized Firms

Ex Ante Business Fields

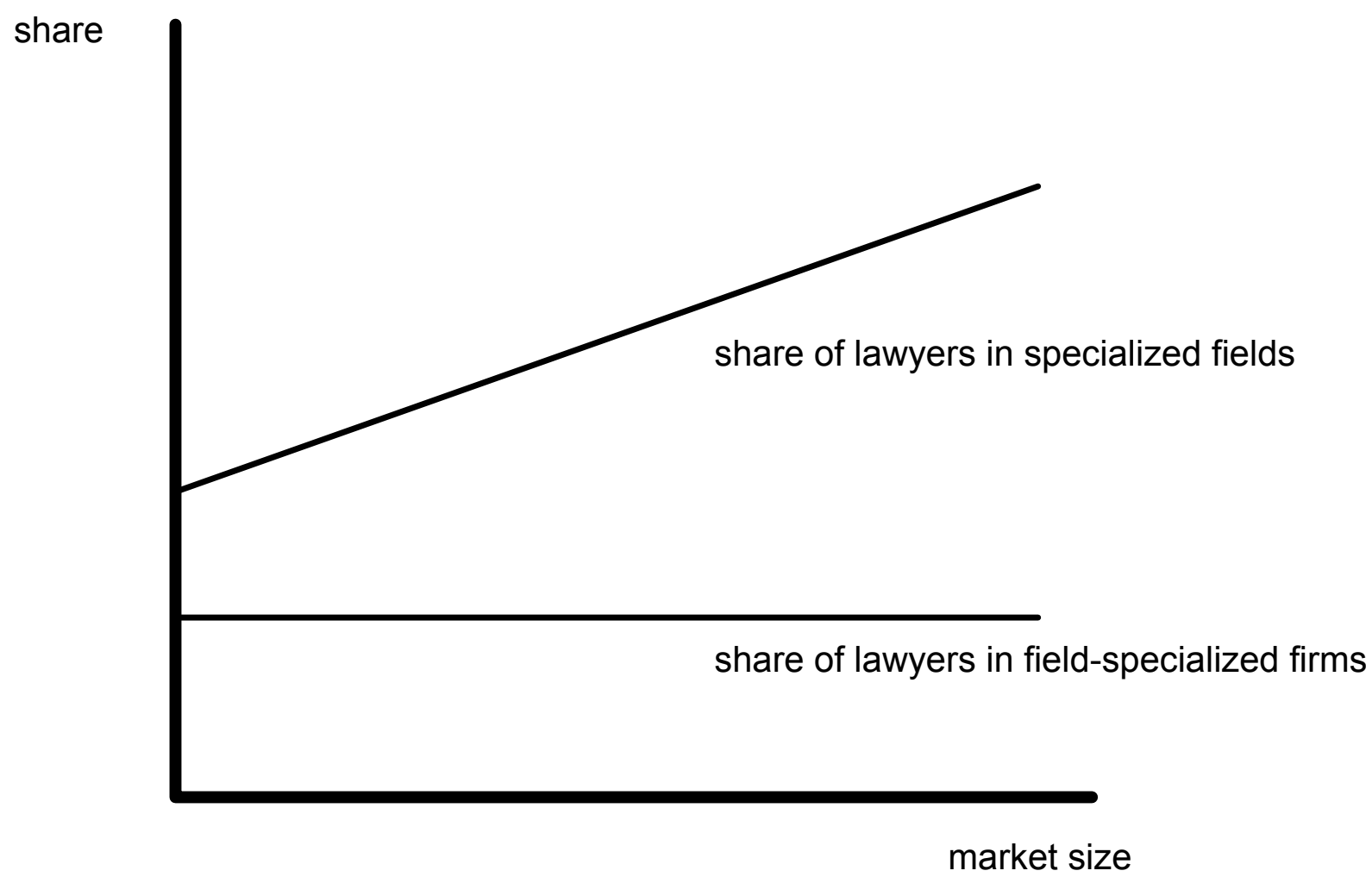


Figure 3

Share of Lawyers in Specialized Fields, Field Specialized Firms

Ex Post Business Fields

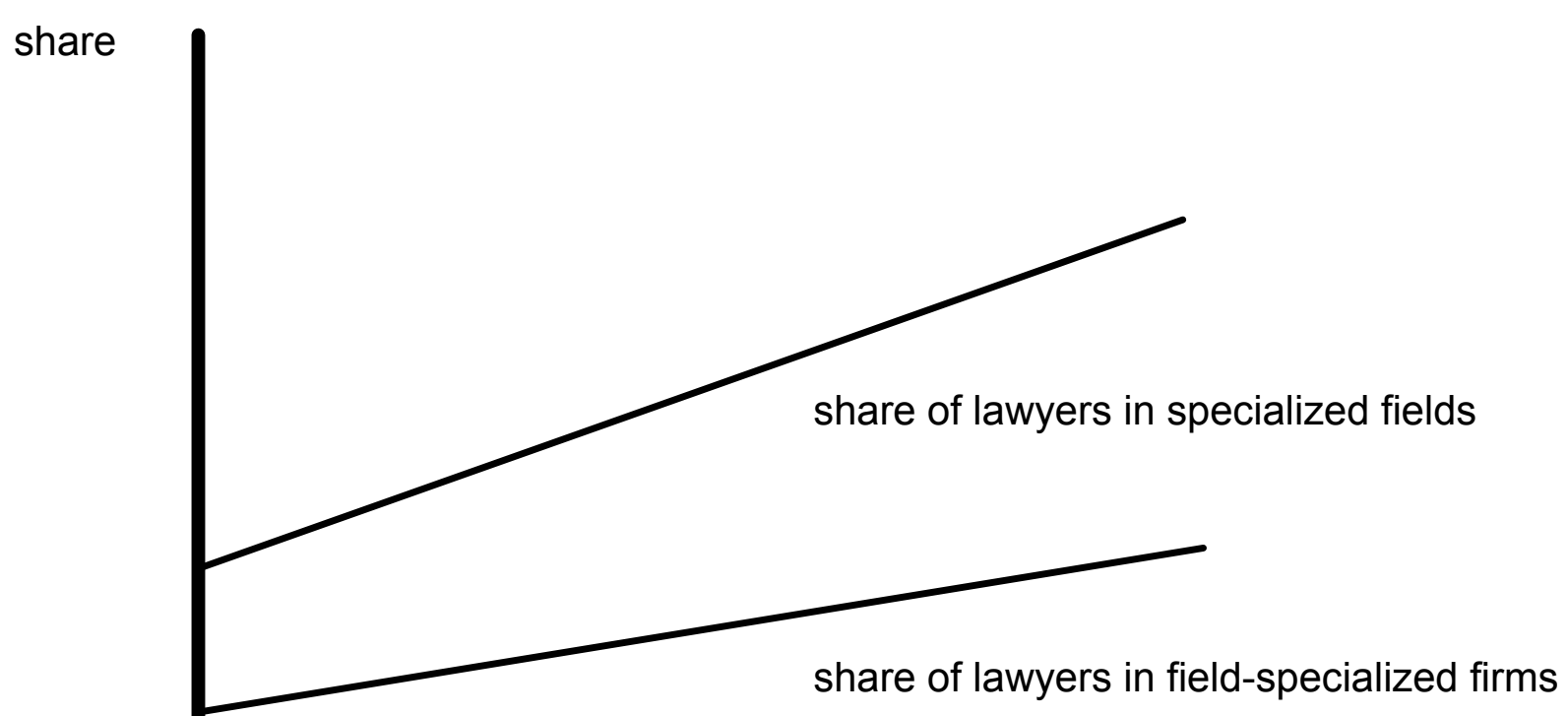

market size 


\section{Appendix 1}

\section{LEGAL SERVICES}

(Form CB-8100)

Item 10. PERSONNEL AND PAYROLL, BY OCCUPATION Include personnel who perform a variety of functions (secretaries, etc.) on the one line which best describes the primary nature of their work

Line a(1) - Lawyers who are members of a professional service corporation should be included here.

Line b-Only proprietors and partners not considered employees of the firm for Federal tax purposes should be included here.

\begin{tabular}{|c|c|c|c|}
\hline $\begin{array}{c}\text { Occupation linclude } \\
\text { proprietors and partners on } \\
\text { line b only) }\end{array}$ & $\begin{array}{c}\text { Personnel for pay } \\
\text { period including } \\
\text { March 12, 1992 } \\
\text { (number) }\end{array}$ & \multicolumn{2}{|c|}{ Annual payroll } \\
\cline { 3 - 4 } & & Mil. & Thou. T, Do \\
\hline
\end{tabular}

a. Type of employee

(1) Associate lawyers (employees of firm)

(2) Paraprofessionals (law clerks, legal assistants, investigators, etc.)

(3) Managers and other nonlegal professional staff

(4) All other (stenographers, bookkeepers, etc.

(5) TOTAL (Sum of lines a(1) through a(4) above should equal entries in items $6 a$ and 7 )

b. Active proprietors or partners at this location (unincorporated operations only)

For law firms operating at more than one location, report proprietors or partners at the location where they spend most of their working time. (If this establishment is a member of a group practice, include only proprietors or partners whose practice is covered by this El Number.)
Item 11. NATURE OF LAWYERS' PRACTICE

Include each individual lawyer reported in items $10 \mathrm{a}(1)$ and $10 \mathrm{~b}$ (associate lawyers plus proprietors and partners at this location) on the one line which best describes the lawyer's primary field of specialization. Lawyers who are not primarily engaged in a single specialized field should be included on line b.

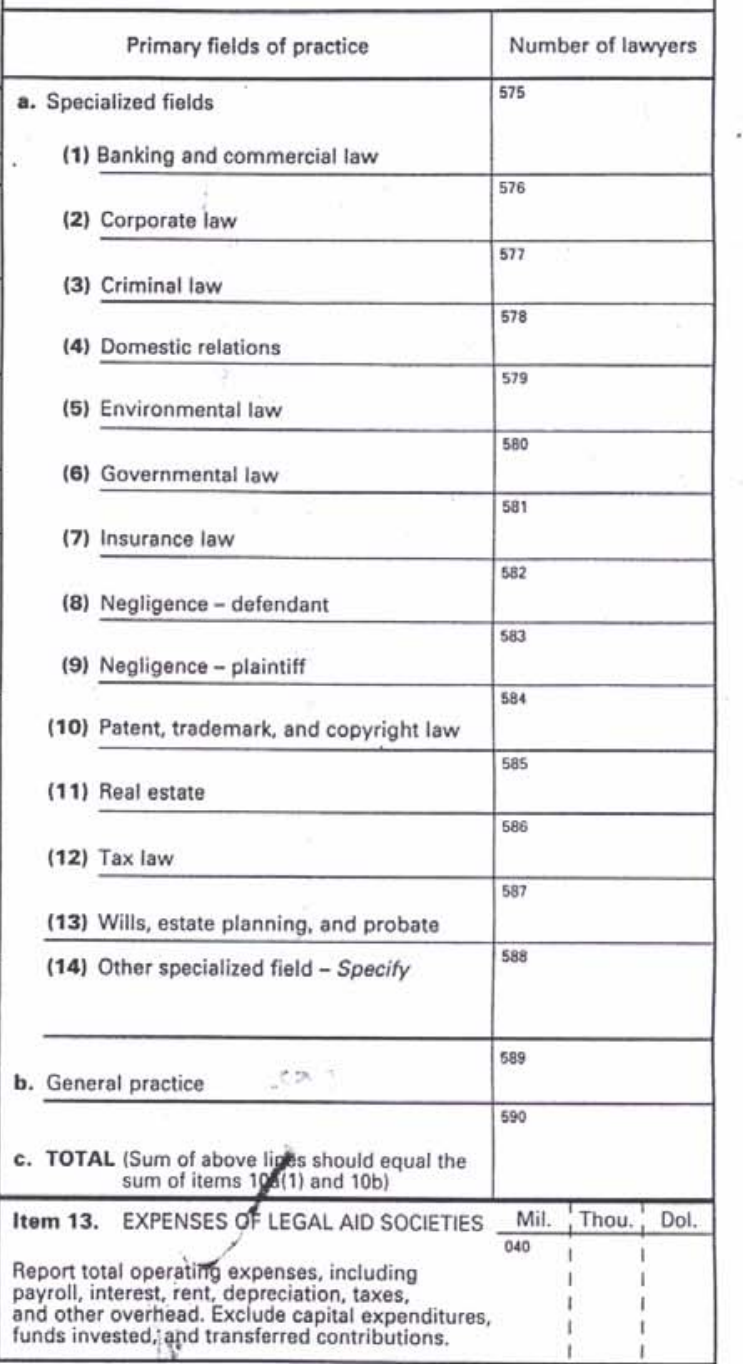

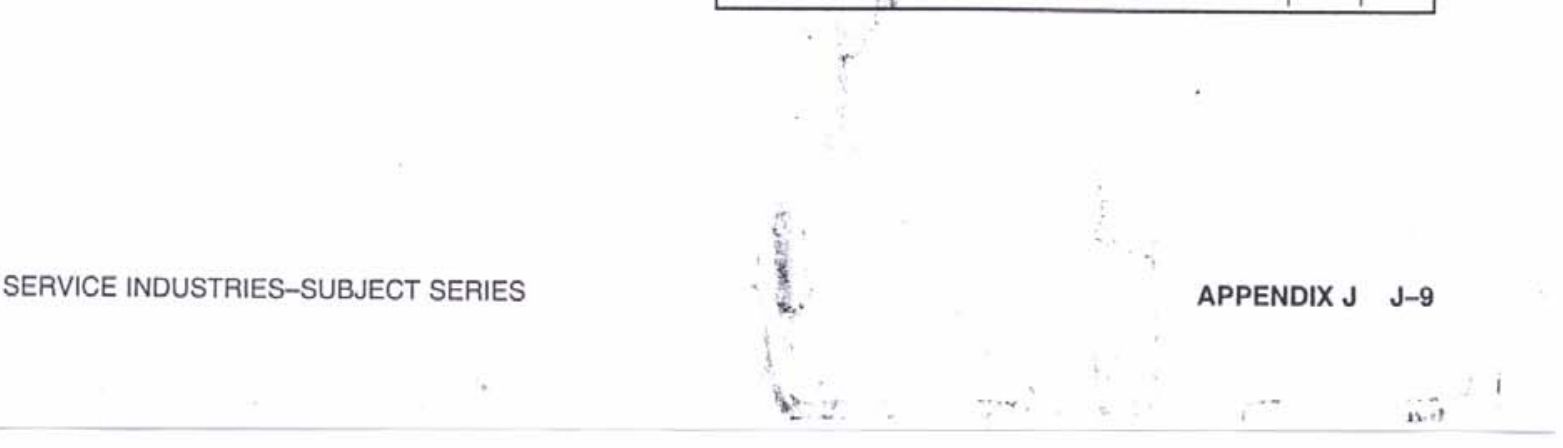




\section{Table A1}

\section{Market Size and Lawyer Specialization}

\begin{tabular}{|c|c|c|c|c|}
\hline Dependent Variable & $\begin{array}{c}\text { Share } \\
\text { Any Specialty }\end{array}$ & $\begin{array}{c}\text { Share } \\
\text { Ex Ante } \\
\text { Business Specialty }\end{array}$ & $\begin{array}{c}\text { Share } \\
\text { Ex Post } \\
\text { Business Specialty }\end{array}$ & $\begin{array}{l}\text { Share } \\
\text { Individual } \\
\text { Speciality }\end{array}$ \\
\hline In(county employment) & $\begin{array}{c}0.083 \\
(0.003)\end{array}$ & $\begin{array}{c}0.020 \\
(0.002)\end{array}$ & $\begin{array}{c}0.021 \\
(0.002)\end{array}$ & $\begin{array}{c}0.017 \\
(0.002)\end{array}$ \\
\hline $\operatorname{sh}(m f g)$ & $\begin{array}{l}-0.515 \\
(0.115)\end{array}$ & $\begin{array}{c}0.259 \\
(0.092)\end{array}$ & $\begin{array}{l}-0.526 \\
(0.084)\end{array}$ & $\begin{array}{l}-0.115 \\
(0.089)\end{array}$ \\
\hline sh(trans/util) & $\begin{array}{l}-0.181 \\
(0.229)\end{array}$ & $\begin{array}{c}0.275 \\
(0.185)\end{array}$ & $\begin{array}{l}-0.287 \\
(0.168)\end{array}$ & $\begin{array}{c}0.191 \\
(0.178)\end{array}$ \\
\hline sh(wholesale) & $\begin{array}{l}-1.052 \\
(0.211)\end{array}$ & $\begin{array}{l}-0.326 \\
(0.171)\end{array}$ & $\begin{array}{c}0.478 \\
(0.155)\end{array}$ & $\begin{array}{l}-0.688 \\
(0.164)\end{array}$ \\
\hline sh(retail) & $\begin{array}{c}0.159 \\
(0.161)\end{array}$ & $\begin{array}{l}-0.206 \\
(0.130)\end{array}$ & $\begin{array}{c}0.055 \\
(0.118)\end{array}$ & $\begin{array}{c}0.591 \\
(0.125)\end{array}$ \\
\hline sh(FIRE) & $\begin{array}{l}-0.119 \\
(0.144)\end{array}$ & $\begin{array}{c}1.285 \\
(0.117)\end{array}$ & $\begin{array}{l}-0.778 \\
(0.106)\end{array}$ & $\begin{array}{l}-0.702 \\
(0.112)\end{array}$ \\
\hline sh(services) & $\begin{array}{c}0.175 \\
(0.119)\end{array}$ & $\begin{array}{c}0.441 \\
(0.096)\end{array}$ & $\begin{array}{c}-0.249 \\
(0.087)\end{array}$ & $\begin{array}{l}-0.165 \\
(0.093)\end{array}$ \\
\hline state capital & $\begin{array}{c}0.028 \\
(0.008)\end{array}$ & $\begin{array}{c}0.042 \\
(0.006)\end{array}$ & $\begin{array}{c}0.007 \\
(0.005)\end{array}$ & $\begin{array}{l}-0.039 \\
(0.006)\end{array}$ \\
\hline emp/estab -- construction & $\begin{array}{c}0.007 \\
(0.001)\end{array}$ & $\begin{array}{c}0.003 \\
(0.001)\end{array}$ & $\begin{array}{c}0.001 \\
(0.001)\end{array}$ & $\begin{array}{c}0.000 \\
(0.001)\end{array}$ \\
\hline emp/estab -- mfg & $\begin{array}{c}0.001 \\
(0.000)\end{array}$ & $\begin{array}{c}0.000 \\
(0.000)\end{array}$ & $\begin{array}{c}0.001 \\
(0.000)\end{array}$ & $\begin{array}{c}0.000 \\
(0.000)\end{array}$ \\
\hline emp/estab -- trans/util & $\begin{array}{c}0.003 \\
(0.001)\end{array}$ & $\begin{array}{c}0.001 \\
(0.000)\end{array}$ & $\begin{array}{c}0.001 \\
(0.000)\end{array}$ & $\begin{array}{l}-0.001 \\
(0.000)\end{array}$ \\
\hline emp/estab -- wholesale & $\begin{array}{l}-0.001 \\
(0.001)\end{array}$ & $\begin{array}{c}0.002 \\
(0.001)\end{array}$ & $\begin{array}{l}-0.006 \\
(0.001)\end{array}$ & $\begin{array}{l}-0.002 \\
(0.001)\end{array}$ \\
\hline emp/estab -- retail & $\begin{array}{l}-0.002 \\
(0.001)\end{array}$ & $\begin{array}{c}0.007 \\
(0.002)\end{array}$ & $\begin{array}{l}-0.001 \\
(0.001)\end{array}$ & $\begin{array}{l}-0.005 \\
(0.002)\end{array}$ \\
\hline emp/estab -- FIRE & $\begin{array}{c}0.003 \\
(0.001)\end{array}$ & $\begin{array}{c}-0.002 \\
(0.001)\end{array}$ & $\begin{array}{c}0.003 \\
(0.001)\end{array}$ & $\begin{array}{c}0.004 \\
(0.001)\end{array}$ \\
\hline emp/estab -- services & $\begin{array}{c}-0.008 \\
(0.002)\end{array}$ & $\begin{array}{c}-0.003 \\
(0.001)\end{array}$ & $\begin{array}{c}0.000 \\
(0.001)\end{array}$ & $\begin{array}{c}0.001 \\
(0.001)\end{array}$ \\
\hline C & $\begin{array}{c}0.463 \\
(0.109)\end{array}$ & $\begin{array}{l}-0.164 \\
(0.088)\end{array}$ & $\begin{array}{c}0.260 \\
(0.080)\end{array}$ & $\begin{array}{c}0.197 \\
(0.085)\end{array}$ \\
\hline
\end{tabular}

$N=26130$ 